\title{
Parkia biglobosa Improves Mitochondrial Functioning and Protects against Neurotoxic Agents in Rat Brain Hippocampal Slices
}

\author{
Kayode Komolafe, ${ }^{1}$ Tolulope M. Olaleye, ${ }^{2}$ Rodrigo L. Seeger, ${ }^{1}$ \\ Fabiano B. Carvalho, ${ }^{1}$ Aline A. Boligon, ${ }^{3}$ Margareth L. Athayde, ${ }^{3}$ Claudia V. Klimaczewski, ${ }^{1}$ \\ Akintunde A. Akindahunsi, ${ }^{2}$ and Joao B. T. Rocha ${ }^{1}$ \\ ${ }^{1}$ Departamento de Bioquímica e Biologia Molecular, CCNE, Universidade Federal de Santa Maria, 97105-900 Santa Maria, RS, Brazil \\ ${ }^{2}$ Department of Biochemistry, School of Sciences, Federal University of Technology, Akure 340001, Nigeria \\ ${ }^{3}$ Departamento de Farmácia Industrial, Universidade Federal de Santa Maria, 97105-900 Santa Maria, RS, Brazil
}

Correspondence should be addressed to Joao B. T. Rocha; jbtrocha@gmail.com

Received 22 February 2014; Revised 26 June 2014; Accepted 28 June 2014; Published 10 August 2014

Academic Editor: Miroslav Pohanka

\begin{abstract}
Copyright (C) 2014 Kayode Komolafe et al. This is an open access article distributed under the Creative Commons Attribution License, which permits unrestricted use, distribution, and reproduction in any medium, provided the original work is properly cited.

Objective. Methanolic leaf extracts of Parkia biglobosa, PBE, and one of its major polyphenolic constituents, catechin, were investigated for their protective effects against neurotoxicity induced by different agents on rat brain hippocampal slices and isolated mitochondria. Methods. Hippocampal slices were preincubated with PBE $(25,50,100$, or $200 \mu \mathrm{g} / \mathrm{mL})$ or catechin $(1,5$, or $10 \mu \mathrm{g} / \mathrm{mL}$ ) for $30 \mathrm{~min}$ followed by further incubation with $300 \mu \mathrm{M} \mathrm{H}_{2} \mathrm{O}_{2}, 300 \mu \mathrm{M} \mathrm{SNP}$, or $200 \mu \mathrm{M} \mathrm{PbCl}_{2}$ for $1 \mathrm{~h}$. Effects of PBE and catechin on SNP- or $\mathrm{CaCl}_{2}$-induced brain mitochondrial ROS formation and mitochondrial membrane potential $(\Delta \Psi m)$ were also determined. Results. PBE and catechin decreased basal ROS generation in slices and blunted the prooxidant effects of neurotoxicants on membrane lipid peroxidation and nonprotein thiol contents. PBE rescued hippocampal cellular viability from SNP damage and caused a significant boost in hippocampus $\mathrm{Na}^{+}, \mathrm{K}^{+}$-ATPase activity but with no effect on the acetylcholinesterase activity. Both $\mathrm{PBE}$ and catechin also mitigated SNP- or $\mathrm{CaCl}_{2}$-dependent mitochondrial ROS generation. Measurement by safranine fluorescence however showed that the mild depolarization of the $\Delta \Psi m$ by PBE was independent of catechin. Conclusion. The results suggest that the neuroprotective effect of $\mathrm{PBE}$ is dependent on its constituent antioxidants and mild mitochondrial depolarization propensity.
\end{abstract}

\section{Introduction}

A significant body of scientific findings supports that excessive generation of ROS and the resulting oxidative stress play a significant role in neurodegenerative diseases [1-3]. Studies with neurodegenerative disease models have shown the involvement of nitric oxide elevation and mitochondrial dysfunction including the accompanying energy breakdown, intraneuronal calcium imbalance with increased expression of apoptotic proteins, and depletion of reduced glutathione levels in tissues [4-6]. Damage to brain cells in many neurodegenerative diseases usually arises from various physiological conditions and external insults that lead to increased free radical production which weakens the brain's antioxidants status and triggers the production of certain proteins and consequently promoting cellular death [7].

Mitochondrial electron transport chain is an important source of ROS generation in the form of superoxide anion radical $\left(\mathrm{O}_{2}{ }^{--}\right)$in somatic cells [8]. The rate of $\mathrm{O}_{2}{ }^{--}$production has been reported to depend on the mitochondrial potential [9]. Of particular neurotoxicological significance, oxidative stress resulting from mitochondrial dysfunction is supposed to be a characteristic of many types of neurodegenerative diseases [10]. Mitochondrial dysfunction has deleterious consequence for cellular function and viability and, depending on the severity of the condition, can result in cellular death [10]. Mitochondria thus control the neuronal cell fate via mediation of apoptotic and necrotic cell death [11]. 
The acetylcholinesterase and $\mathrm{Na}^{+}, \mathrm{K}^{+}$-ATPase enzymes are of considerable importance to neuronal functions. The latter is responsible for the consumption of about $50 \%$ of ATP generated in the brain cellular membrane which is utilized for the maintenance and reestablishing of the electrochemical gradients necessary for neuronal excitability and regulation of neuronal cell volume. The activity of the $\mathrm{Na}^{+}, \mathrm{K}^{+}$-ATPase enzyme is known to decrease under certain pathophysiology conditions related to psychiatric disorders [12].

This whole set of knowledge suggests that compounds or natural products with beneficial effects on mitochondrial membrane function and antioxidant status might be of pharmacological usefulness in modulating or counteracting mitochondrial dysfunction in neurodegenerative diseases. In this regard, natural products or bioactive components with antioxidant and neuroprotective properties have been reported to exhibit preventive or therapeutic effects on experimental models of brain oxidative stress [13-16].

Parkia biglobosa (Jacq.) Benth., commonly known as "African locust bean," is perennial deciduous tree with extensive uses in West Africa for food, medicine, and timber. The tree is known as Igi iru or Irugba among the Yoruba people of South-Western Nigeria where the seeds are fermented to make a strong smelling and tasty soup condiment rich in protein popularly called Iru [17]. It has popular ethnomedicinal use in tropical Africa in the treatment of hypertension and fevers [18-20] and as a major constituent of herbal preparations used as neurostimulant and in treatment of fatigue in South-Western Nigeria (oral communications by local herbal practitioners). In vitro antioxidant property of the crude ethanolic extract of the leaf and stem bark was reported [19]. We observed a potent antioxidant activity and beneficial effect of the methanolic leaf extract of the plant on isolated hepatic mitochondria [21] and recently reported the hypoglycemic effect of its constituent saponins mixture [22].

To the best of our knowledge, there is no data on the effect of $P$. biglobosa on brain mitochondrial integrity or its neuroprotective effect in the literature. The present study was therefore conducted to fill this lacuna by providing scientific information on the effect of P. biglobosa on enzymes of neurological significance, brain mitochondrial redox status, and hippocampal neuronal cell damage induced by different neurotoxicants in rats.

\section{Materials and Methods}

2.1. Chemicals. Ouabain octahydrate, adenosine triphosphate (ATP), acetylthiocholine iodide, 3(4,5-dimethylthiazol-2-yl)-2,5-diphenyltetrazolium bromide (MTT), dichlorofluorescein diacetate (DCFH-DA), 5, $5^{1}$-dithiobis-(2-nitrobenzoic acid)(DTNB), catechin, (-) epigallocatechin, (-) epigallocatechin gallate, quercetin, rutin, and kaempferol were acquired from Sigma Chemical Co. (St. Louis, MO, USA). Dibasic phosphate potassium $\left(\mathrm{K}_{2} \mathrm{HPO}_{4}\right)$, monobasic phosphate potassium $\left(\mathrm{KH}_{2} \mathrm{PO}_{4}\right)$, and trichloroacetic acid (TCA) were supplied by Vetec (Rio de Janeiro, RJ, Brazil). All chemicals and solvents were of analytical grade and the water used was glass distilled.
2.2. Plant Material. Fresh leaves of Parkia biglobosa were collected in Isua-Akoko, Ondo State, Nigeria. Botanical identification and authentication were carried out by Dr. Ugbogu A. O. and Mr. Shasanya O. S. at the herbarium of the Forestry Research Institute (FRIN) Ibadan, Oyo State, Nigeria, where a voucher specimen (number 109603) was deposited.

2.3. Parkia biglobosa Extract Preparation. Air-dried leaves were ground to fine powder using a blender. A $500 \mathrm{~g}$ sample of the powdered material was macerated in $1200 \mathrm{~mL}$ of a mixture of methanol and water $(4: 1)$ for 48 hours. The filtrate obtained was concentrated to a small volume to remove the entire methanol using rotary evaporator. The concentrated extract was then lyophilized and kept at $-20^{\circ} \mathrm{C}$ until required $[23,24]$. Extract yield was approximately $11 \%$. In each case, extract was reconstituted in water to give specific concentrations (in $\mathrm{mg} / \mathrm{mL}$ or $\mathrm{mg} / \mathrm{mL}$ ) prior to use.

2.4. Quantification of Phenolics. High performance liquid chromatography (HPLC-DAD) was performed with a Shimadzu Prominence Auto Sampler (SIL-20A) HPLC system (Shimadzu, Kyoto, Japan), equipped with Shimadzu LC20AT reciprocating pumps connected to a DGU 20A5 degasser with a CBM 20A integrator, SPD-M20A diode array detector, and LC solution 1.22 SP1 software. Reverse phase chromatography analyses were carried out under gradient conditions using a Phenomenex C-18 column $(4.6 \mathrm{~mm} \times$ $150 \mathrm{~mm}$ ) packed with $5 \mu \mathrm{m}$ diameter particles. The mobile phase was water containing $2 \%$ acetic acid (A) and methanol (B), and the composition gradient was $5 \%$ of B until 2 min and was changed to obtain $25 \%, 40 \%, 50 \%, 60 \%, 70 \%$, and $100 \%$ $\mathrm{B}$ at $10,20,30,40,50$, and $60 \mathrm{~min}$, respectively, following the method described by Sabir et al. [25] with slight modifications. Methanolic leaf extract of Parkia biglobosa, PBE, was analyzed after dissolution in methanol at a concentration of $10 \mathrm{mg} / \mathrm{mL}$. The presence of nine compounds was investigated, namely, gallic acid, chlorogenic acid, caffeic acid, catechin, epigallocatechin, epigallocatechin gallate, quercetin, rutin, and kaempferol. Identification of these compounds was performed by comparing their retention time and UV absorption spectrum with those of the commercial standards. The flow rate was $0.8 \mathrm{~mL} / \mathrm{min}$, injection volume was $50 \mu \mathrm{L}$, and the wavelength were $254 \mathrm{~nm}$ for gallic acid, 280 for catechin, epigallocatechin, and epigallocatechin gallate, $325 \mathrm{~nm}$ for chlorogenic and caffeic acids, and $365 \mathrm{~nm}$ for quercetin, rutin, and kaempferol. All the samples and mobile phase were filtered through $0.45 \mu \mathrm{m}$ membrane filter (Millipore) and then degassed by ultrasonic bath prior to use. Stock solutions of standards references were prepared in the HPLC mobile phase at a concentration range of $0.020-0.200 \mathrm{mg} / \mathrm{mL}$ for catechin, epigallocatechin, epigallocatechin gallate, quercetin, rutin. and kaempferol and $0.030-0.250 \mathrm{mg} / \mathrm{mL}$ for gallic, chlorogenic, and caffeic acids. The chromatography peaks were confirmed by comparing the retention time with those of reference standards and by DAD spectra (200 to $500 \mathrm{~nm})$. All chromatography operations were carried out at ambient temperature and in triplicate. The limit of detection (LOD) and limit of quantification (LOQ) were calculated based on 
the standard deviation of the responses and the slope using three independent analytical curves, as defined by ICH [26]. LOD and LOQ were calculated as 3.3 and $10 \sigma / S$, respectively, where $\sigma$ is the standard deviation of the response and $\mathrm{S}$ is the slope of the calibration curve.

2.5. Animals. Male Wistar rats ( \pm 3 months old), weighing between 270 and $320 \mathrm{~g}$, from the University breeding colony (Animal House Holding, UFSM, Brazil), were kept in cages with free access to foods and water in a room with controlled temperature $\left(22^{\circ} \mathrm{C} \pm 3\right)$ and in $12 \mathrm{~h}$ light/dark cycle with lights on at 7:00 a.m. The animals were maintained and used in accordance to the guidelines of the Brazilian association for laboratory animal science. All efforts were made to minimize animal suffering and to reduce the number of animals used.

2.6. Preparation of Brain Hippocampal Slices. Rats were decapitated, brains removed, and hippocampi dissected $\left(4^{\circ} \mathrm{C}\right)$ in artificial cerebrospinal fluid (aCSF) containing (in $\mathrm{mM}$ ) $120 \mathrm{NaCl}, 0.5 \mathrm{KCl}, 35 \mathrm{NaHCO}_{3}, 1.5 \mathrm{CaCl}_{2}, 1.3 \mathrm{MgCl}_{2}$, $1.25 \mathrm{Na}_{2} \mathrm{HPO}_{4}$, and $10 \mathrm{D}$-glucose ( $\mathrm{pH}$ 7.4) [16]. Transverse sections $(400 \mu \mathrm{m})$ were prepared using a McIlwain tissue chopper (Campden instruments). The slices were preincubated at $37^{\circ} \mathrm{C}$ for $20 \mathrm{~min}$ before the start of each experiment.

2.7. Reactive Oxygen Species (ROS) Measurement. Fluorescent probes of $2^{\prime}, 7^{\prime}$-dichlorofluorescein diacetate (DCFHDA) were employed in the determination of intracellular reactive species formation in hippocampal cells. The slices (4 slices per well) were incubated in aCSF in the presence of four concentrations of $\operatorname{PBE}(25,50,100$, or $200 \mu \mathrm{g} / \mathrm{mL})$ or three concentrations of catechin $(1,5$, or $10 \mu \mathrm{g} / \mathrm{mL})$ for $1 \mathrm{~h}$ and $30 \mathrm{~min}$. Control slices in the present assay and others were treated with the appropriate volume of vehicle-distilled water. Slices of each sample were removed and homogenized in $1 \mathrm{~mL}$ of buffer before centrifuging at $3000 \times \mathrm{g}$ for $10 \mathrm{~min}$. To $200 \mu \mathrm{L}$ of the supernatant, $5 \mu \mathrm{M}$ DCFH-DA was added and ROS production in the slice homogenates was quantified by measuring the formation of the fluorescence product of DCFH oxidation (i.e., DCF). DCF fluorescence was monitored for $30 \mathrm{~min}$ at $2 \mathrm{~min}$ interval using excitation and emission wavelengths of $488 \mathrm{~nm}$ and $525 \mathrm{~nm}$, respectively, in a microplate reader (SpectraMax M2e Multi-Mode, USA) as described by Wagner et al. [16]. Autooxidation of DCFH-DA was also measured in the absence of slices homogenate and the values were subtracted in each of the cases.

2.8. Assessment of Hippocampal Cellular Viability. Cellular viability assay was performed by the colorimetric 3(4,5-dimethylthiazol-2-yl)-2,5-diphenyl tetrazolium bromide (MTT) method. MTT is widely used as an indicator of the mitochondrial activity of living cells which are capable of reducing the dye into a purple formazan product that is soluble in dimethyl sulfoxide (DMSO) [27]. The slices (4 slices per tube) were incubated in aCSF buffer in the presence of any of $\mathrm{SNP}(300 \mu \mathrm{M}), \mathrm{H}_{2} \mathrm{O}_{2}(300 \mu \mathrm{M})$, or $\mathrm{PbCl}_{2}(200$ $\mu \mathrm{M})$ for $1 \mathrm{~h}$ and after pretreating in each case with four concentrations of $\mathrm{PBE}(25,50,100$, or $200 \mu \mathrm{g} / \mathrm{mL})$ or three concentration of catechin $(1,5$, or $10 \mu \mathrm{g} / \mathrm{mL})$ for $30 \mathrm{~min}$. In another experiment, slices were treated with either PBE (25, $50,100$, or $200 \mu \mathrm{g} / \mathrm{mL})$ or catechin $(1,5$, or $10 \mu \mathrm{g} / \mathrm{mL})$ alone to determine the effect of extract and its major flavonoid, catechin, on brain hippocampal cellular viability. $10 \mu \mathrm{L}$ of MTT $(5 \mathrm{mg} / \mathrm{mL}$, for a final concentration of $50 \mu \mathrm{g} / \mathrm{mL}$ ) was added and the plates were incubated for an additional $30 \mathrm{~min}$ at $37^{\circ} \mathrm{C}$. Slices were removed and introduced into DMSO for complete extraction of the color. The optical density was measured using microplate reader (SpectraMax M2e Multi-Mode reader, USA) at 540 and $700 \mathrm{~nm}$, and the net A540-A700 was taken as an index of cell viability [28]. Furthermore, the potential interference of the extract and some of the flavonoids (catechin, quercetin, and rutin) found in the extract (Figure 1) in the MTT reduction, without slices was investigated. The interference of these compounds and PBE was less than $1 \%$ of that observed in the presence of slices (data not shown). Thus, in 30 min of incubation, the chemical reduction of MTT by PBE or flavonoids was negligible.

\subsection{Determination of Lipid Peroxidation in Hippocampal} Slices. Measurement of lipid peroxidation was performed by detection of TBA-reactive substances as previously described [29] with slight modification. The slices (5 slices per tube) were incubated in an artificial cerebrospinal fluid (aCSF) in the presence or absence of any of SNP $(300 \mu \mathrm{M}), \mathrm{H}_{2} \mathrm{O}_{2}$ $(300 \mu \mathrm{M})$, or $\mathrm{PbCl}_{2}(200 \mu \mathrm{M})$ for $1 \mathrm{~h}$ after preincubation in each case with four concentrations of PBE $(25,50,100$, or $200 \mu \mathrm{g} / \mathrm{mL})$ or three concentration of catechin $(1,5$, or $10 \mu \mathrm{g} / \mathrm{mL}$ ) for $30 \mathrm{~min}$. Hippocampal slices from each sample were then homogenized in $200 \mu \mathrm{L}$ of aCSF buffer. $50 \mu \mathrm{L}$ of homogenates was used for measurement of peroxidation by addition of $8.1 \%$ SDS $(50 \mu \mathrm{L}), 1.35 \mathrm{M}$ acetic acid buffer, pH $3.4(120 \mu \mathrm{L})$, and $0.8 \%$ TBA $(80 \mu \mathrm{L})$. The final solution was incubated at $100^{\circ} \mathrm{C}$ for $1 \mathrm{~h}$. After cooling the samples on ice, they were centrifuged at 3,000 $\mathrm{g}$ for $10 \mathrm{~min}$ and the absorbance of the respective supernatants was measured spectrophotometrically at $532 \mathrm{~nm}$ using a microplate reader. The results were calculated as nmol of thiobarbituric reactive substances (TBARS) per mg of protein. The protein concentrations were determined by the method of Bradford [30] using bovine serum albumin (BSA) as standard.

2.10. Determination of Nonprotein Thiols (NPSH) Levels in Slices. Preincubation of hippocampal slices with PBE or catechin and treatment with toxicants proceeded as explained under lipid peroxidation determination. NPSH was determined by the method of Ellman [31] with slight modifications. Slices from each sample were homogenized in $10 \mathrm{mM}$ Tris- $\mathrm{HCl}, \mathrm{pH}$ 7.4. Briefly, a total of $100 \mu \mathrm{L}$ of tissue homogenates was precipitated with $50 \mu \mathrm{L}$ of $10 \%$ TCA $(1: 1$ $\mathrm{v} / \mathrm{v}$ ) before subjecting to centrifugation at $3,000 \times \mathrm{g}$ at $4^{\circ} \mathrm{C}$ for $10 \mathrm{~min}$. Free -SH groups were determined in the proteinfree clear supernatant $(40 \mu \mathrm{L})$ in an assay mixture containing $150 \mu \mathrm{L}$ of potassium phosphate buffer $(1 \mathrm{M}, \mathrm{pH} 7.4)$ and $10 \mu \mathrm{L}$ DTNB $(10 \mathrm{mM})$. The yellow color that developed was read at $412 \mathrm{~nm}$ in a microplate reader (SpectraMax M2e Multi-Mode, 


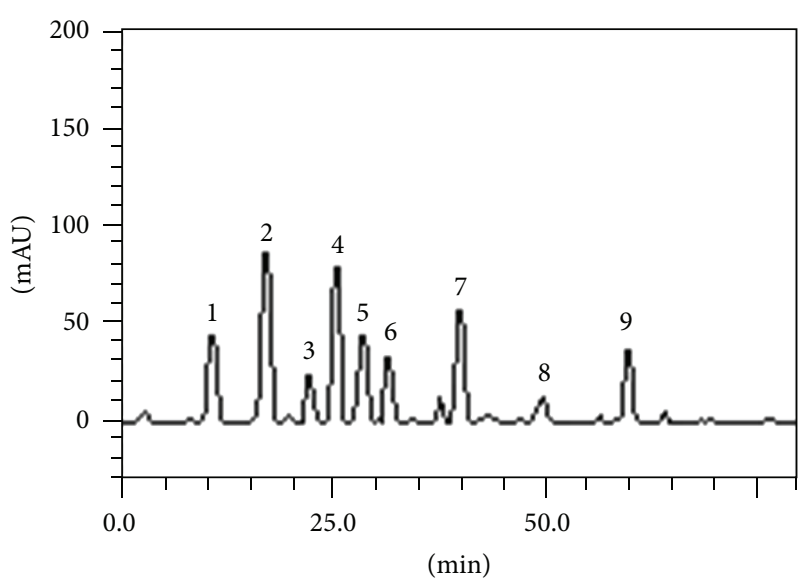

FIGURE 1: Representative high performance liquid chromatography profile of Parkia biglobosa leaf. ${ }^{a}$ Detection UV was at $325 \mathrm{~nm}$. Gallic acid (peak 1), catechin (peak 2), chlorogenic acid (peak 3), caffeic acid (peak 4), epigallocatechin (peak 5), epigallocatechin gallate (peak 6), rutin (peak 7), quercetin (peak 8), and kaempferol (peak 9).

USA). The NPSH levels were calculated as $\mu \mathrm{mol} \mathrm{NPSH} / \mathrm{mg}$ of protein.

2.11. $\mathrm{Na}^{+}, \mathrm{K}^{+}$-ATPase Activity Determination. The $\mathrm{Na}^{+}, \mathrm{K}^{+}$ATPase activity was measured in slices homogenate incubated with PBE or catechin as described by Wyse et al. [32] but with minor modifications. The assay medium consisted of (in mM) 30 Tris- $\mathrm{HCl}$ buffer (pH 7.4), 0.1 EDTA, $50 \mathrm{NaCl}, 5$ $\mathrm{KCl}, 6 \mathrm{MgCl}_{2}$, and $50 \mu \mathrm{g}$ of protein in the presence or absence of ouabain $(1 \mathrm{mM})$, in a final volume of $350 \mu \mathrm{L}$. The reaction was started by the addition of adenosine triphosphate to a final concentration of $3 \mathrm{mM}$. After $30 \mathrm{~min}$ at $37^{\circ} \mathrm{C}$, the reaction was stopped by the addition of $70 \mu \mathrm{L}$ of $50 \%$ (w/v) trichloroacetic acid. Appropriate controls were included in the assays for nonenzymatic hydrolysis of ATP. The amount of inorganic phosphate $(\mathrm{Pi})$ released was quantified as previously described [33], using $\mathrm{NaH}_{2} \mathrm{PO}_{4}$ as reference standard. Specific $\mathrm{Na}^{+}, \mathrm{K}^{+}$-ATPase activity was calculated by subtracting the ouabain-insensitive activity from the overall activity (in the absence of ouabain) and expressed in $\mathrm{nmol}$ of $\mathrm{Pi} / \mathrm{mg}$ of protein/min.

2.12. Determination of Acetylcholinesterase Activity. AChE activity was measured by the slightly modified spectrophotometric method of Ellman et al. [34]. Briefly, in this method, $100 \mu \mathrm{L}$ of sodium phosphate buffer $(100 \mathrm{mM}, \mathrm{pH}$ 7.5) containing $10 \mathrm{mM} \mathrm{DTNB}, 10 \mu \mathrm{L}$ of test solutions (PBE $25,50,100$, and $200 \mu \mathrm{g} / \mathrm{mL}$ or catechin 1,5 , and $10 \mu \mathrm{g} / \mathrm{mL}$ concentrations) and $10 \mu \mathrm{L}$ of whole brain homogenate were added in a 96-well microplate and incubated for $5 \mathrm{~min}$ at $25^{\circ} \mathrm{C}$. The reaction was then initiated with the addition of $20 \mu \mathrm{L}$ of acetylthiocholine iodide $(8 \mathrm{mM})$. Hydrolysis of acetylthiocholine iodide was monitored by the formation of the yellow 5-thio-2-nitrobenzoate anion as a result of the reaction of DTNB with thiocholines catalysed by enzymes at $412 \mathrm{~nm}$ utilizing a 96-well microplate reader (SpectraMax M2e Multi-Mode reader, USA).

2.13. Isolation of Fresh Brain Mitochondria. Brain mitochondria were isolated as previously described by Brustovetsky and Dubinsky [35] with minor modifications. Wistar rats were killed by decapitation and the whole brain tissues were rapidly removed and placed on ice-cold isolation buffer containing $225 \mathrm{mM}$ mannitol, $75 \mathrm{mM}$ sucrose, $1 \mathrm{mM}$ EGTA, $0.1 \%$ bovine serum albumin (BSA; free fatty acid), and $10 \mathrm{mM}$ HEPES pH 7.2. The tissues were then homogenized and the resulting suspension centrifuged for $7 \mathrm{~min}$ at $2,000 \times \mathrm{g}$. Next, the supernatant was centrifuged for $10 \mathrm{~min}$ at $12,000 \times \mathrm{g}$. The pellet was resuspended in isolation buffer II containing $225 \mathrm{mM}$ mannitol, $75 \mathrm{mM}$ sucrose, $1 \mathrm{mM}$ EGTA, and $10 \mathrm{mM}$ HEPES pH 7.2 and centrifuged at $12,000 \times \mathrm{g}$ for $10 \mathrm{~min}$. Finally, the last supernatant was discarded, and the pellet was resuspended and maintained in buffer III (sucrose $100 \mathrm{mM}$, $\mathrm{KCl} 65 \mathrm{mM}, \mathrm{K}^{+}$-HEPES $10 \mathrm{mM}$, and EGTA $50 \mu \mathrm{M} \mathrm{pH} 7.2$ ) to a protein concentration of $0.5 \mathrm{mg} / \mathrm{mL}$ for subsequent analyses.

2.14. Evaluation of Reactive Species (RS) Formation with Dichlorofluorescein-Reactive Species (DCFH-RS). RS levels were measured using the oxidant sensing fluorescent probe, $2^{\prime}, 7^{\prime}$-dichlorofluorescein diacetate (DCFH-DA) [36]. The oxidation of DCFH (which is formed by the action of esterase on DCFH-DA) to fluorescent dichlorofluorescein (DCF) was determined at $488 \mathrm{~nm}$ for excitation and $525 \mathrm{~nm}$ for emission. An aliquot of $5 \mu \mathrm{L}$ ( $50 \mu \mathrm{g}$ protein) of the homogenate of the isolated mitochondria was added to $3 \mathrm{~mL}$ of buffer III (containing $5 \mathrm{mM}$ succinate). The reaction medium was exposed to $\operatorname{PBE}(25,50$, or $100 \mu \mathrm{g} / \mathrm{mL})$ or catechin $(1,5$, or $10 \mu \mathrm{g} / \mathrm{mL})$ and/or $80 \mu \mathrm{M} \mathrm{Ca}^{2+} / 150 \mu \mathrm{M}$ SNP. After $10 \mathrm{~s}, 10 \mu \mathrm{M}$ (DCFH-DA) (prepared in ethanol) was added to the mixture and the fluorescence intensity from DCF was measured for $300 \mathrm{~s}$ using a spectrofluorimeter (RF-5301 Shimadzu, Kyoto, Japan).

\subsection{Measurement of Mitochondrial Membrane Potential} $(\Delta \psi m)$. Mitochondrial membrane potential was estimated by fluorescence changes of safranin [37] recorded by a RF5301 Shimadzu spectrofluorimeter (Kyoto, Japan) operating at excitation and emission wavelengths of 495 and $586 \mathrm{~nm}$, respectively, with slit widths of $3 \mathrm{~nm}$. Values of mitochondrial membrane potential $(\Delta \psi m)$ were expressed relative to the control.

2.16. Statistical Analysis. Experiments conducted in replicates were expressed as mean \pm standard error of the mean (SEM). Data on mitochondrial ROS production was analyzed using two-way analysis of variance followed by Bonferroni posttest to account for the two variables of time and concentration. Unless otherwise stated, other data were analyzed using one-way analysis of variance followed by the NewmanKeuls post hoc test. 


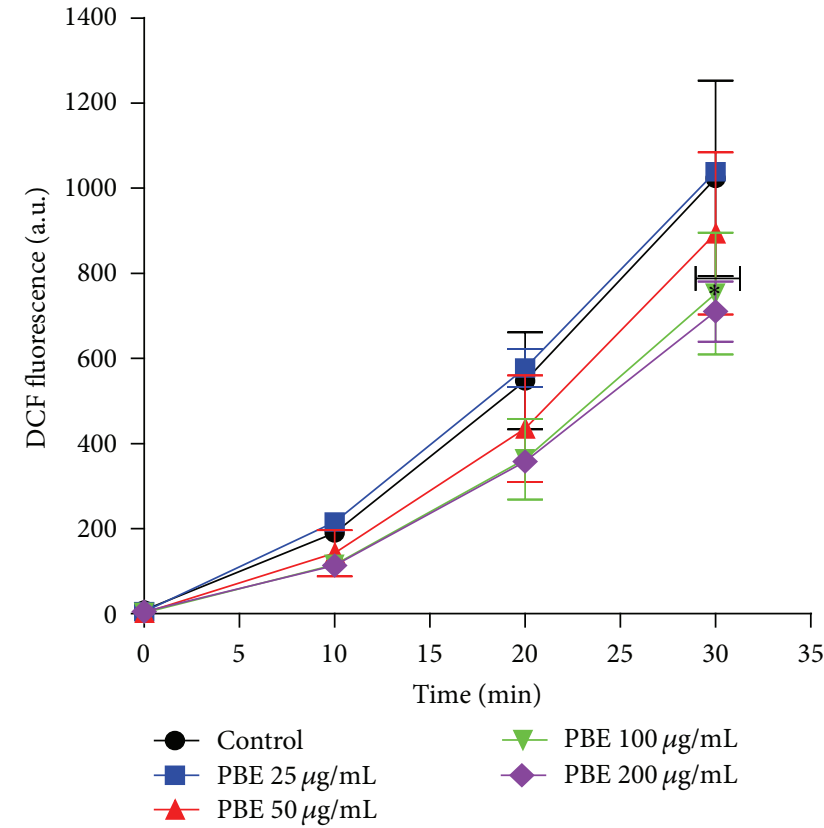

(a)

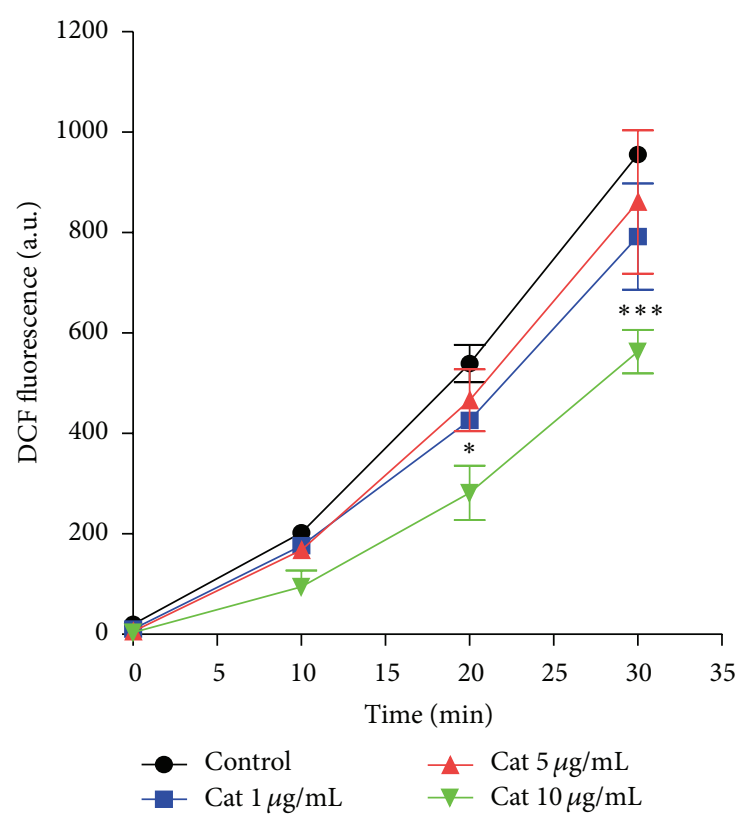

(b)

FIGURE 2: Effect of PBE (a) and catechin (b) on basal ROS generation in rats' brain hippocampal slices. Hippocampal slices were incubated in the presence or absence of Parkia biglobosa extract, PBE $(25,50,100$, or $200 \mu \mathrm{g} / \mathrm{mL})$, or catechin $(1,5$, or $10 \mu \mathrm{g} / \mathrm{mL})$. Slices of each sample were then homogenized to obtain the supernatant in which ROS production was quantified by reacting with $5 \mu \mathrm{M}$ DCFH-DA. Data of ROS levels are presented as fluorescence intensity emission and expressed as mean \pm SEM of three independent assays. Data analysis was done by two-way ANOVA, followed by Bonferroni posttests $(P<0.05$ was considered statistically significant). Statistically significant mitigation of basal ROS generation was achieved at 100 and $200 \mu \mathrm{g} / \mathrm{mL}$ concentration of PBE (a) and $10 \mu \mathrm{g} / \mathrm{mL}$ concentration of catechin $(\mathrm{b}) .{ }^{*} P<0.05$ and ${ }^{* * *} P<0.001$ versus untreated slices (control).

\section{Results}

3.1. HPLC Analysis. HPLC analysis revealed the presence of flavonoids (catechin, epigallocatechin, epigallocatechin gallate quercetin, rutin, and kaempferol), and phenolic acids (gallic, chlorogenic, and caffeic acids) in the methanolic extract of Parkia biglobosa leaf (PBE). The chromatogram revealed the presence of gallic acid (retention time, $t_{R}=$ $11.78 \mathrm{~min} ; 1.53 \%$; peak 1$)$, catechin $\left(t_{R}=17.08 \mathrm{~min} ; 2.94 \%\right.$; peak 2$)$, chlorogenic acid $\left(t_{R}=22.97 \mathrm{~min} ; 0.64 \%\right.$; peak 3$)$, caffeic acid $\left(t_{R}=25.36 \mathrm{~min} ; 2.81 \%\right.$; peak 4$)$, epigallocatechin $\left(t_{R}=28.67 \mathrm{~min} ; 1.50 \%\right.$; peak 5$)$, epigallocatechin gallate $\left(t_{R}=\right.$ 32.05 min; $1.12 \%$; peak 6), rutin $\left(t_{R}=39.83 \mathrm{~min}\right.$; $1.75 \%$; peak $7)$, quercetin $\left(t_{R}=48.54 \mathrm{~min} ; 0.41 \%\right.$; peak 8$)$, and kaempferol $\left(t_{R}=60.15 \mathrm{~min}\right.$; 1.27\%; peak 9) (Figure 1 and Table 1 ).

The results were similar to that obtained earlier on the same extract analyzed after dissolving in ethanol (unpublished data). The present analysis however made use of more standards for comparison.

3.2. Attenuation of Intracellular ROS Accumulation by PBE and Catechin. As shown in Figure 2, PBE caused dosedependent decrease in basal ROS formation in hippocampal slices with the decrease becoming statistically significant at 100 and $200 \mu \mathrm{g} / \mathrm{mL}$ concentrations. Catechin caused significant reduction in DCFH oxidation at $10 \mu \mathrm{g} / \mathrm{mL}$ concentration.
TABLE 1: Phenolic and flavonoid compositions of methanolic leaf extract of Parkia biglobosa.

\begin{tabular}{lcccc}
\hline \multirow{2}{*}{ Compounds } & \multicolumn{2}{c}{ Parkia biglobosa } & LOD & LOQ \\
& $\mathrm{mg} / \mathrm{g}$ & Percent & $\mu \mathrm{g} / \mathrm{mL}$ & $\mu \mathrm{g} / \mathrm{mL}$ \\
\hline Gallic acid & $15.38 \pm 0.01$ & 1.53 & 0.017 & 0.056 \\
Catechin & $29.42 \pm 0.02$ & 2.94 & 0.044 & 0.145 \\
Chlorogenic acid & $6.43 \pm 0.05$ & 0.64 & 0.036 & 0.119 \\
Caffeic acid & $28.19 \pm 0.01$ & 2.81 & 0.009 & 0.028 \\
Epigallocatechin & $15.04 \pm 0.03$ & 1.50 & 0.007 & 0.023 \\
Epigallocatechin & $11.25 \pm 0.02$ & 1.12 & 0.016 & 0.054 \\
gallate & $17.52 \pm 0.01$ & 1.75 & 0.022 & 0.074 \\
Rutin & $4.16 \pm 0.01$ & 0.41 & 0.028 & 0.092 \\
Quercetin & $12.79 \pm 0.03$ & 1.27 & 0.031 & 0.103 \\
Kaempferol & &
\end{tabular}

Results are expressed as mean \pm standard deviations (SD) of three determinations.

3.3. Improvement of Cellular Viability/Mitochondrial Function by PBE and Catechin. One-way ANOVA followed by the Newman-Keuls multiple comparison test revealed that treatment of hippocampal slices with PBE or catechin alone had no statistically significant effect on hippocampal cellular viability/mitochondrial function at the tested concentrations. A significant loss of cellular viability in SNP-treated slices 


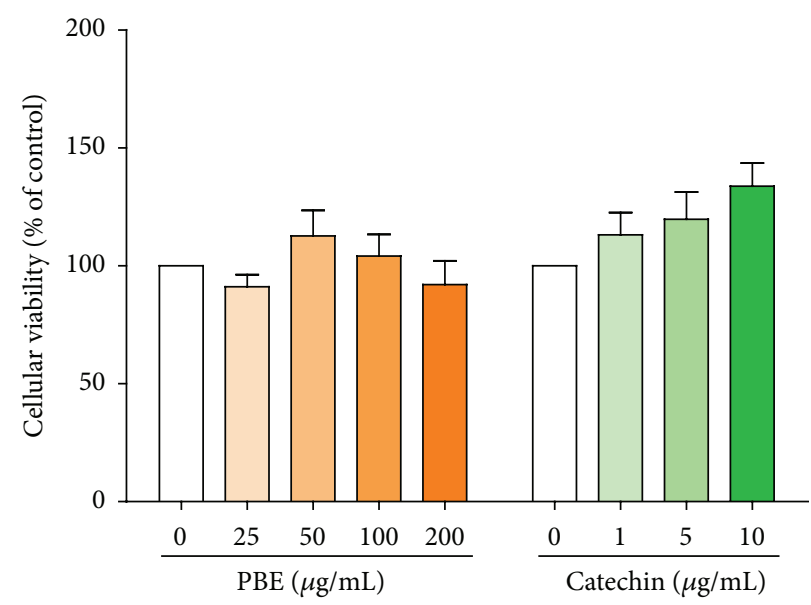

(a)

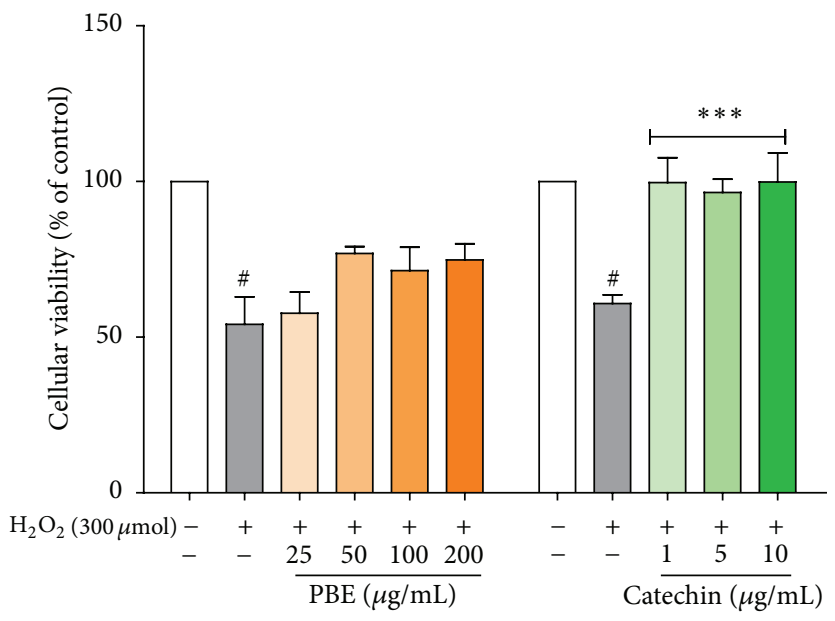

(c)

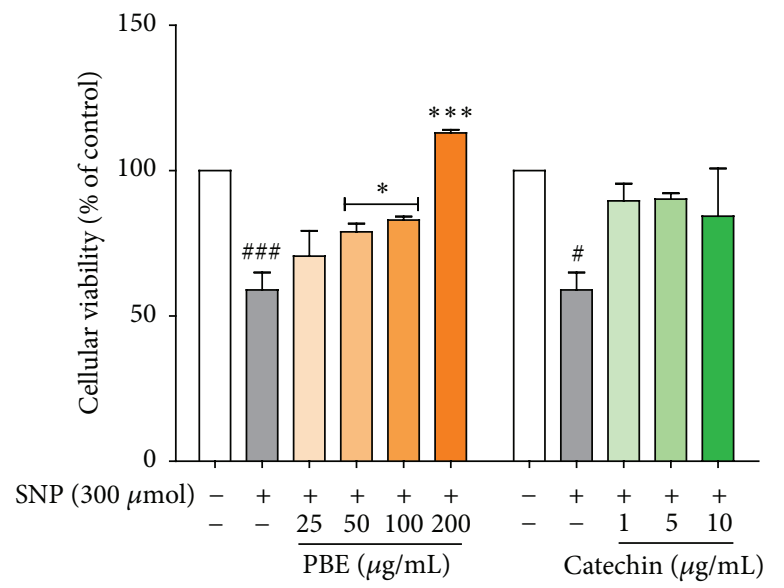

(b)

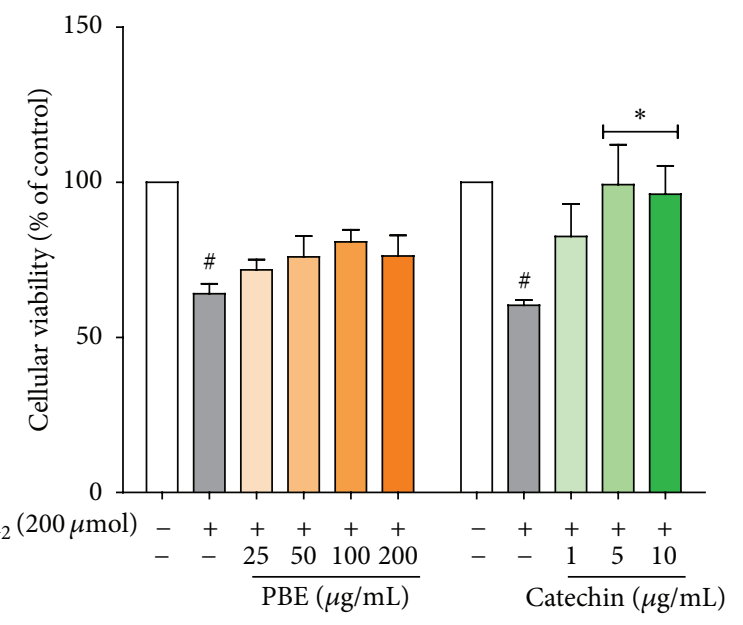

(d)

FIGURE 3: Modulation of cellular viability by PBE and catechin. Hippocampal brain slices were incubated with either P. biglobosa extract, $\operatorname{PBE}(25,50,100$, or $200 \mu \mathrm{g} / \mathrm{mL})$, or catechin $(1,5$, or $10 \mu \mathrm{g} / \mathrm{mL})$ alone for $1 \mathrm{~h} 30 \mathrm{~min}$ or preincubated with the same for $30 \mathrm{~min}$ before final incubation with any of the toxicants $\left(\mathrm{SNP}, \mathrm{H}_{2} \mathrm{O}_{2}\right.$, or $\mathrm{PbCl}_{2}$ ) for $1 \mathrm{~h}$. The net color intensity of the purple formazan product formed following MTT staining and measured at $540 \mathrm{~nm}$ and $700 \mathrm{~nm}$ wavelengths (A540-A700) was taken as index of cellular viability. Data are expressed as mean \pm SEM of three independent experiments. ${ }^{\#}<0.05$, ${ }^{\# \#} P<0.01$, and ${ }^{\# \#} P<0.001$ versus untreated slices (control) and ${ }^{*} P<0.05$, ${ }^{* *} P<0.01$, and ${ }^{* * *} P<0.001$ versus slices treated with toxicants ( $\mathrm{SNP}, \mathrm{H}_{2} \mathrm{O}_{2}$, or $\mathrm{PbCl}_{2}$ ) alone, as determined by one-way ANOVA followed by the Newman-Keuls multiple comparison test.

was however observed. Pretreatment with PBE protected hippocampal slices from SNP-induced mitochondrial damage assessed by MTT reduction in a dose-dependent manner but the improvement by catechin was not significant (Figure 3(b)). $\mathrm{H}_{2} \mathrm{O}_{2}$-dependent decrease in viable hippocampal cells was blunted in catechin pretreated slices but the inhibition of $\mathrm{H}_{2} \mathrm{O}_{2}$ effect on slices by PBE was not statistically significant at any of the concentrations used (Figure 3(c)). Pretreatment with 5 or $10 \mu \mathrm{g} / \mathrm{mL}$ concentration of catechin had beneficial effect on $\mathrm{PbCl}_{2}$ toxicity as it prevented $\mathrm{PbCl}_{2}$ dependent loss of hippocampal cells viability (Figure 3(d)).

\subsection{Attenuation of Hippocampal Cells Membrane Lipid Per-} oxidation. The toxicity of SNP $(300 \mu \mathrm{M})$ to the hippocampal cells was manifested by the increased rate of membrane lipid peroxidation. Statistically significant decrease in toxicant-induced peroxidation of hippocampal cells membranes was achieved by $200 \mu \mathrm{g} / \mathrm{mL}$ PBE (Figure 4(a); $P<$ 0.01 ) or 5 and $10 \mu \mathrm{g} / \mathrm{mL}$ catechin (Figure $4(\mathrm{a}) ; P<0.001$ ). Attenuation of $\mathrm{H}_{2} \mathrm{O}_{2}$-induced increase in hippocampal cells TBARs generation was evident in 50 and $100 \mu \mathrm{g} / \mathrm{mL} \mathrm{PBE}$ pretreated (Figure $4(\mathrm{~b}) ; P<0.05$ ) or 5 and $10 \mu \mathrm{g} / \mathrm{mL}$ catechin pretreated (Figure 4(b); $P<0.01$ ) hippocampal slices. As shown in Figure 4(c), similar protective effect against $\mathrm{PbCl}_{2}$ dependent damage was observed for slices pretreated with both $\mathrm{PBE}$ and catechin, respectively.

3.5. Effect of PBE and Catechin on Nonprotein Thiol (NPSH) Contents. Reduced glutathione (GSH) comprises the bulk of cellular nonprotein thiol groups (NPSH). NPSH was significantly decreased in SNP $(300 \mu \mathrm{M}), \mathrm{H}_{2} \mathrm{O}_{2}(300 \mu \mathrm{M})$, and $\mathrm{PbCl}_{2}(200 \mu \mathrm{M})$ treated slices that were without prior 


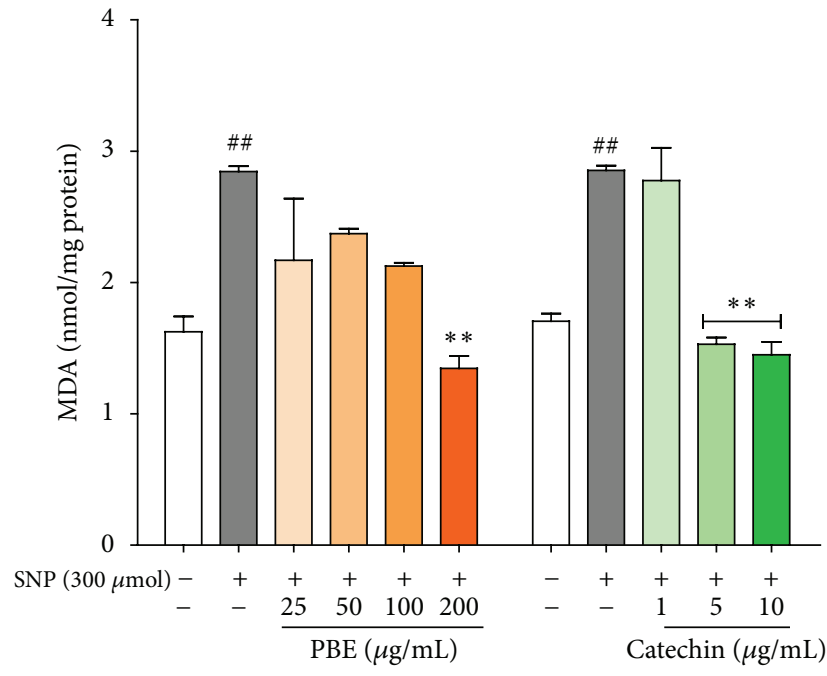

(a)

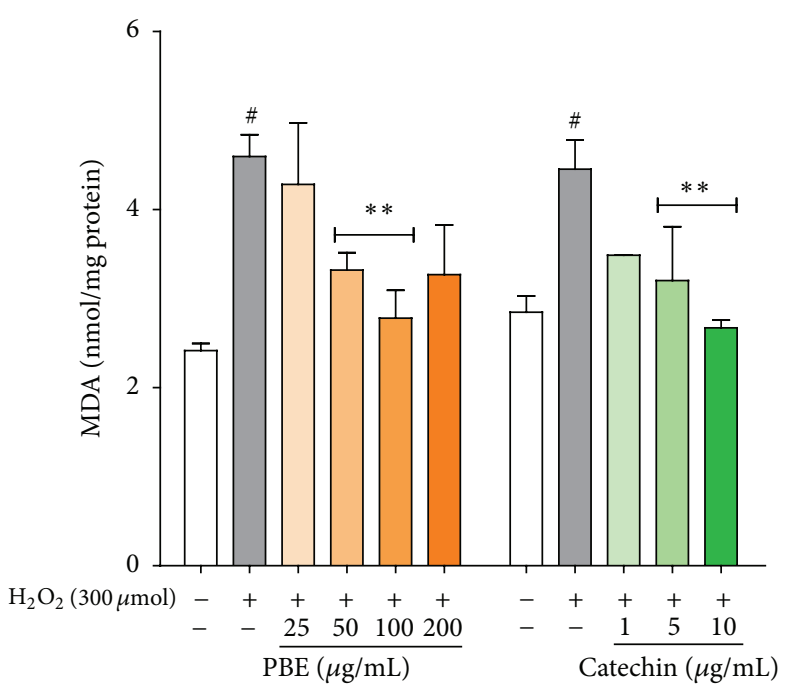

(b)

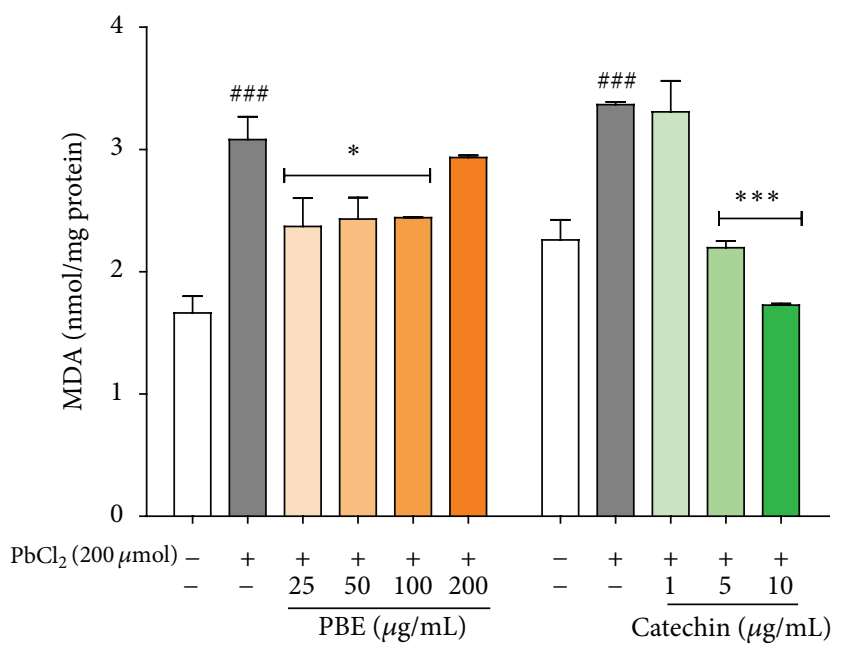

(c)

FIGURE 4: Attenuation of membrane lipid peroxidation in hippocampal cells by PBE and catechin. Hippocampal brain slices were preincubated with P. biglobosa extract, $\operatorname{PBE}(25,50,100$, or $200 \mu \mathrm{g} / \mathrm{mL})$, or catechin $(1,5$, or $10 \mu \mathrm{g} / \mathrm{mL})$ for $30 \mathrm{~min}$ before final incubation with toxicants (SNP, $\mathrm{H}_{2} \mathrm{O}_{2}$, or $\mathrm{PbCl}_{2}$ ) for $1 \mathrm{~h}$. Thiobarbituric acid reactive species (TBARs) were quantified in slices homogenate and used as index of membrane lipid peroxidation. Data are expressed as mean \pm SEM of three independent experiments. ${ }^{\#} P<0.05$, ${ }^{\# \#} P<0.01$, and ${ }^{\# \# \#} P<0.001$ versus untreated slices (control) and ${ }^{*} P<0.05,{ }^{* *} P<0.01$, and ${ }^{* * *} P<0.001$ versus slices treated with toxicants $\left(\mathrm{SNP}_{2} \mathrm{H}_{2} \mathrm{O}_{2}, \mathrm{or}^{\mathrm{PbCl}} \mathrm{Pb}_{2}\right)$ alone, as determined by one-way ANOVA followed by the Newman-Keuls multiple comparison test.

pretreatment. $\operatorname{PBE}(50,100$, and $200 \mu \mathrm{g} / \mathrm{mL})$ pretreated slices showed increased NPSH levels in both cases of toxicant induction such that no significant difference could be observed when compared with normal, untreated slices (control). As can be observed in Figures 5(a), 5(b), and 5(c) also, similar boost in cellular nonprotein thiol contents was shown by catechin pretreated slices. Apparently, both PBE and catechin are involved in mechanisms capable of boosting cellular thiol contents under conditions of oxidative stress.

3.6. Effect of PBE on $\mathrm{Na}^{+}, \mathrm{K}^{+}$-ATPase Activity. $\mathrm{Na}^{+}, \mathrm{K}^{+}$ATPase activity was significantly increased in PBE-treated slices (Figure 6(a); $P<0.05$ ) but no effect was observed for catechin-treated slices. Both PBE and catechin however did not affect cerebral acetylcholinesterase activity at the evaluated concentrations.

3.7. PBE and Catechin Decrease Mitochondrial ROS Production. Figures 7(a) and 7(b) show the effect of PBE and catechin on basal ROS formation in the mitochondria. Statistical analysis revealed that $\mathrm{PBE}$ reduced mitochondrial oxidative stress at 50 and $100 \mu \mathrm{g} / \mathrm{mL}$ concentrations $(P<0.001)$ but the same feat was achieved by catechin only at $1 \mu \mathrm{g} / \mathrm{mL}$ concentration.

Figures 7(c) and 7(d) show the effect of Parkia biglobosa leaf extract $(\mathrm{PBE})$ and catechin on brain mitochondrial 


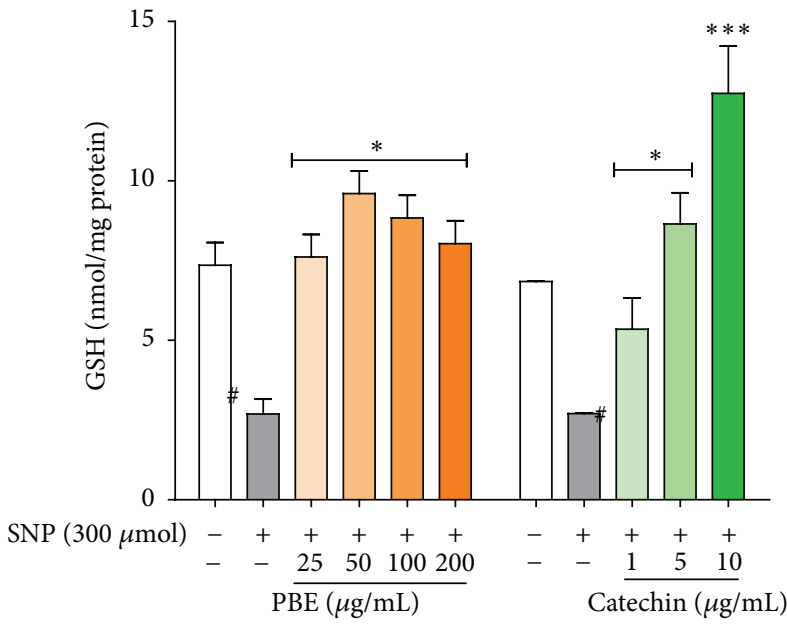

(a)

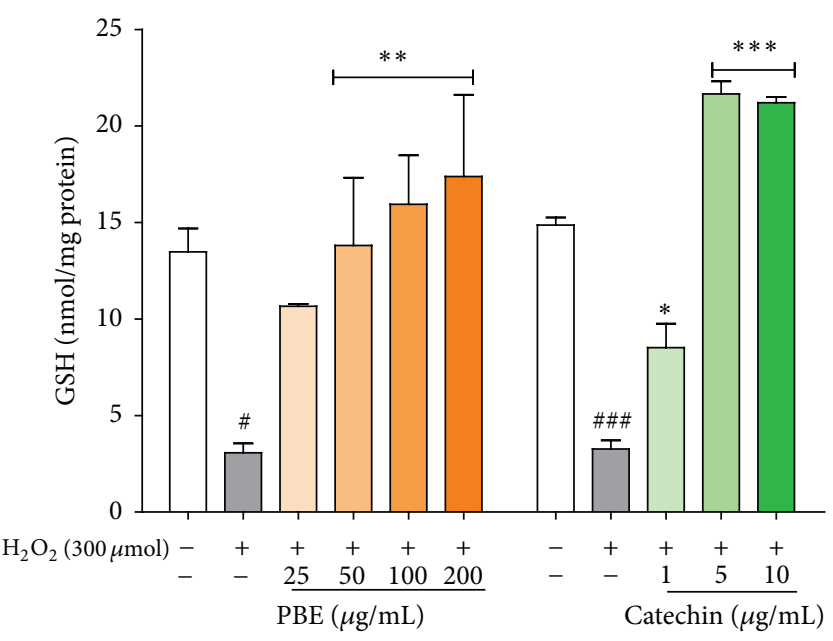

(b)

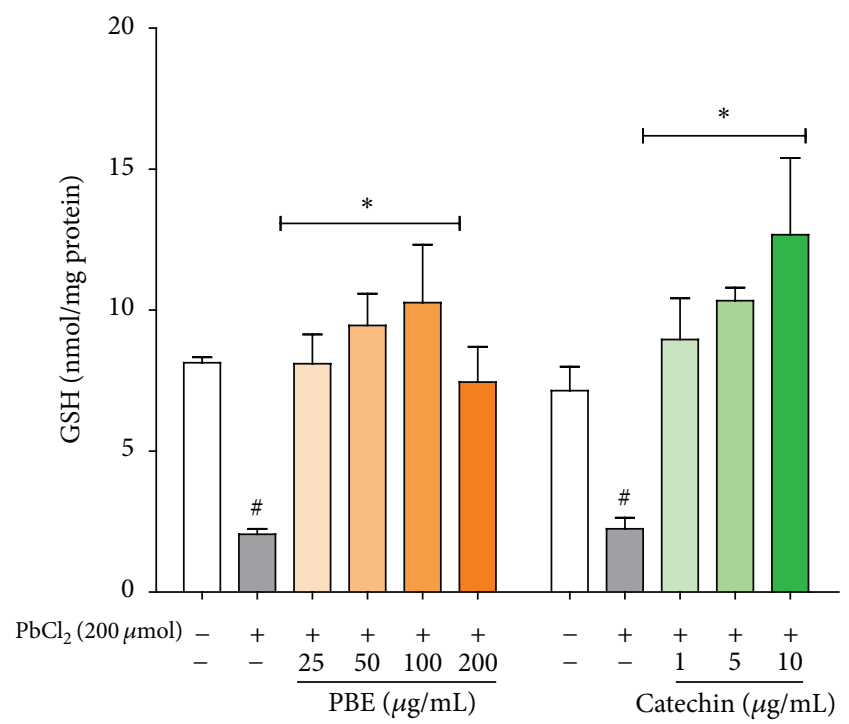

(c)

FIGURE 5: Effect of PBE and catechin on nonprotein thiol content. Hippocampal brain slices were preincubated with $P$. biglobosa extract, PBE $(25,50,100$, or $200 \mu \mathrm{g} / \mathrm{mL})$, or catechin $(1,5$, or $10 \mu \mathrm{g} / \mathrm{mL})$ for $30 \mathrm{~min}$ before final incubation with toxicants $\left(\mathrm{SNP}_{2} \mathrm{H}_{2} \mathrm{O}_{2}\right.$, or $\left.\mathrm{PbCl} \mathrm{l}_{2}\right)$ for $1 \mathrm{~h}$. Slices homogenates were deproteinized and the free - $\mathrm{SH}$ groups were quantified in the protein-free supernatant by measuring the intensity of the color produced on reacting with Ellman's reagent at $412 \mathrm{~nm}$. Data are expressed as mean \pm SEM of three independent experiments. ${ }^{\#} P<0.05$ and ${ }^{\# \#} P<0.01$ versus untreated slices (control) and ${ }^{*} P<0.05$ and ${ }^{* * *} P<0.001$ versus slices treated with toxicants $\left(\mathrm{SNP}, \mathrm{H}_{2} \mathrm{O}_{2}\right.$, or $\mathrm{PbCl}_{2}$ ) alone, as determined by one-way ANOVA followed by the Newman-Keuls multiple comparison test.

ROS production: interaction with SNP. Two-way ANOVA of data from Figures 7(c) and 7(d)yielded a significant main effect of SNP induction and a significant interaction between this factor and P. biglobosa and catechin concentrations, respectively. As can be observed, SNP caused an increase in DCFH oxidation, whereas all concentrations of PBE and two concentrations of catechin $(1$ and $5 \mu \mathrm{g} / \mathrm{mL}$ ) blunted the increase in oxidative stress production.

Figures 7(e) and 7(f) show the effect of Parkia biglobosa leaf extract (PBE) and catechin, respectively, on brain mitochondrial ROS production and the interaction with $\mathrm{Ca}^{2+}$. Similar to the observation under SNP induction, all concentrations of PBE and two concentrations of catechin (1 and $5 \mu \mathrm{g} / \mathrm{mL}$ ) inhibited the $\mathrm{Ca}^{2+}$ increase in DCFH oxidation to DCF.

3.8. PBE Exhibits Mild Mitochondrial Depolarization Potential. As shown in Figure 8(b), PBE caused dose-dependent but mild depolarization of the brain mitochondrial potential $(\Delta \Psi m)$ which only becomes statistically significant at the highest concentration of $100 \mu \mathrm{g} / \mathrm{mL}(P<0.01)$ whereas catechin at the evaluated concentrations showed no effect on the brain mitochondrial potential (Figure 8(d)). 


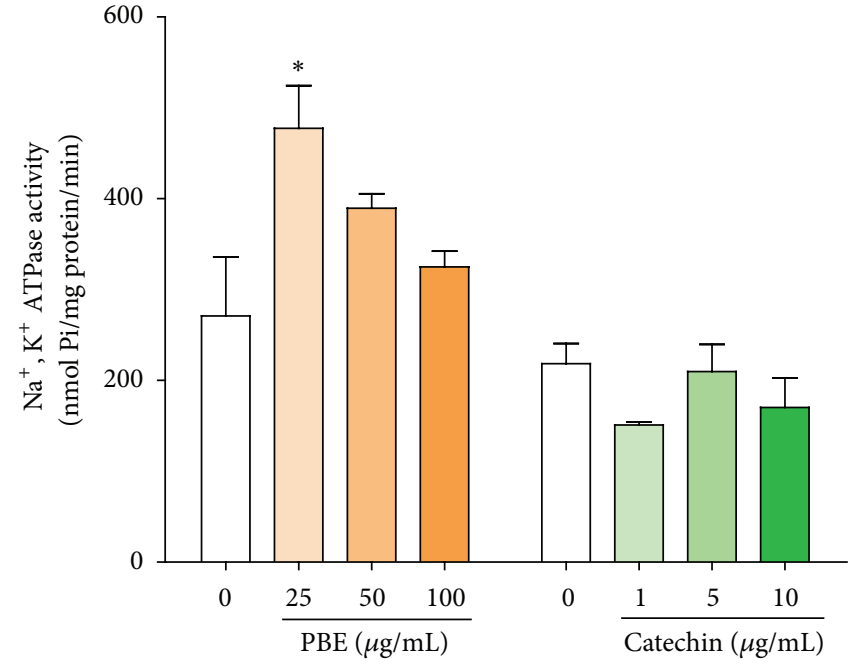

(a)

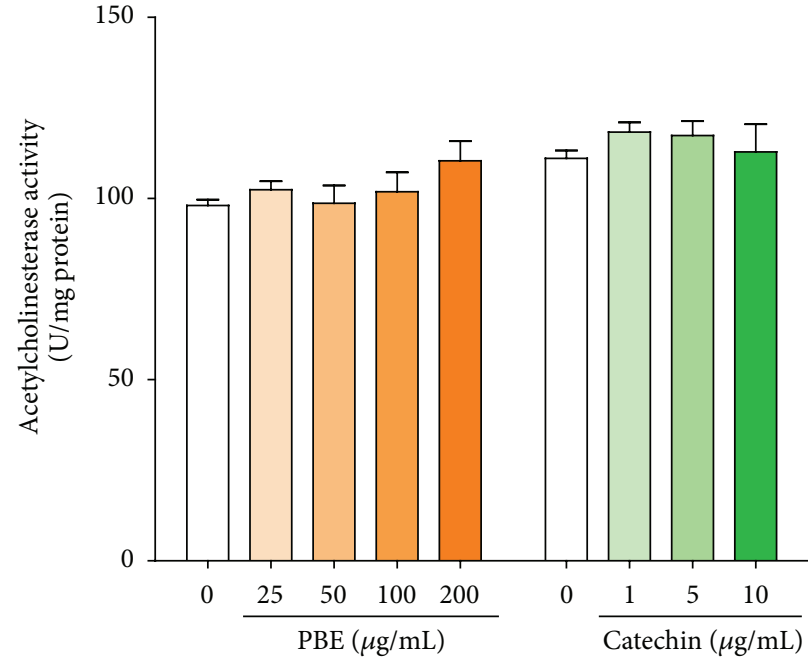

(b)

Figure 6: Effect of PBE and catechin on cerebral enzymes activities. Effect of PBE and catechin on $\mathrm{Na}^{+}, \mathrm{K}^{+}$-ATPase (a) and total acetylcholinesterase activities (b) in rats' brain hippocampal slices homogenate. Hippocampal slices were preincubated with $P$. biglobosa extract, $\operatorname{PBE}(25,50,100$, or $200 \mu \mathrm{g} / \mathrm{mL})$, or catechin $(1,5$, or $10 \mu \mathrm{g} / \mathrm{mL})$ for $1 \mathrm{~h}$ and $30 \mathrm{~min}$. Slices homogenates were assayed for the activity of $\mathrm{Na}^{+}, \mathrm{K}^{+}$-ATPase. Data are expressed as mean \pm SEM of three independent experiments. ${ }^{*} P<0.05$ versus untreated slices/homogenate (control), as determined by one-way ANOVA followed by the Newman-Keuls multiple comparison test.

\section{Discussion}

Plants and plant-products will continue to find relevance in the treatment and management of numerous diseases and/or pathological conditions especially in the low-income countries due to their ready accessibility and inexpensive nature. The relatively safer and nontoxic nature of these natural products is also believed to give them an edge over their synthetic counterparts. HPLC analysis of the phenolics in the leaf of $P$. biglobosa revealed that the flavan-3-ols, catechin, epicatechin, and epigallocatechin, represent considerable portion of phenolics in the leaf with catechin being the most abundant. Catechin was therefore chosen as the reference phenolic in the present study and the concentration range investigated was based on the empirical evidence presented by the HPLC results. Catechin polyphenols in green tea were identified to be paramount to the neuroprotective properties of the green tea plant majorly through their strong antioxidant, free radical scavenging, and metal ion chelating activities [38]. They could also exhibit beneficial effects on the mitochondrial redox status $[39,40]$.

In the present study, we have investigated the effect of a leaf extract of a medicinal plant, $P$. biglobosa, and catechin on key enzymes of neurological significance and brain hippocampal slices toxicity induced by different neurotoxicants. Additionally, their effects on isolated brain mitochondrial ROS production and membrane potential were also investigated in realization of the involvement of these mitochondria parameters in neurotoxicity and in the pathology of many neurodegenerative diseases $[10,11]$. The choice of hippocampus is based on the observation that this part of the brain is particularly sensitive to stress effects [41]. In this study, we sought to establish the relationship between the purported neuroprotectivity of $P$. biglobosa and the constituent phenolics and shed some lights on the underlying mechanism(s).

We observed a reduction in basal ROS generation in hippocampal slices with both PBE and catechin although the effect of catechin on basal ROS generation in the mitochondria was only significant at the lowest concentration. Mitigation of ROS generation by both PBE and catechin might be responsible for their ability to protect against the loss of hippocampal cellular viability in the presence of neurotoxicants. In consistence with Bastianetto and Quirion [42], exposure of rat hippocampal cells to SNP could have decreased cellular survival through increased mitochondrial production of reactive oxygen species (ROS). The catechin polyphenol and some other polyphenolics were capable of protecting hippocampal cells against SNP-induced toxicity and the neuroprotection might be more related to their antioxidant properties without involving the intracellular enzymes such as the $\mathrm{NO}$ synthase [43]. Mitigation of $\mathrm{H}_{2} \mathrm{O}_{2}$-induced hippocampal membrane peroxidation and prevention of the depletion of nonprotein thiol contents by PBE can also be related to the antioxidant phenolic constituents of which catechin is principal. The reactive oxygen species, $\mathrm{H}_{2} \mathrm{O}_{2}$, are produced in large quantities during redox processes and are capable of inducing membrane lipid peroxidation, DNA damage, and eventually leading to apoptosis in different cell types [44]. Therapeutic strategies aimed at preventing ROS effects including cellular apoptosis hold promises for the treatments of the numerous diseases in which excessive ROS generation is involved in their etiology [45]. Exposure to neurotoxic metals like lead $(\mathrm{Pb})$ still occurs at relatively higher and toxicologically significant levels in the developing world 


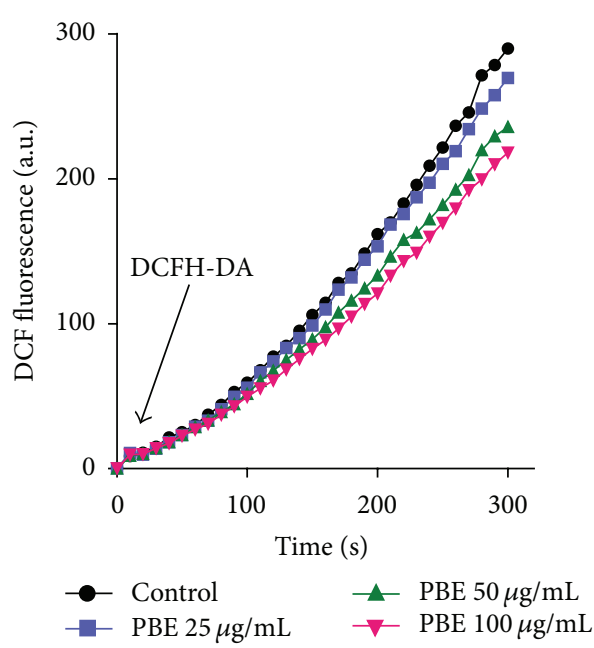

(a)

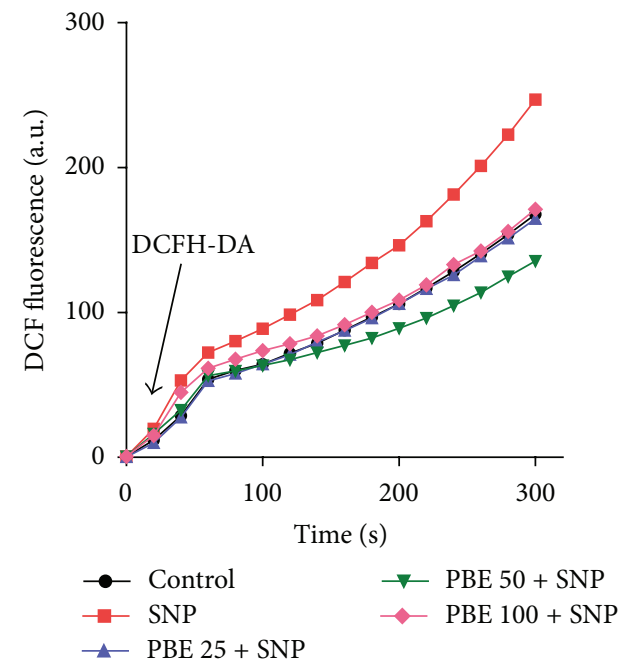

(c)

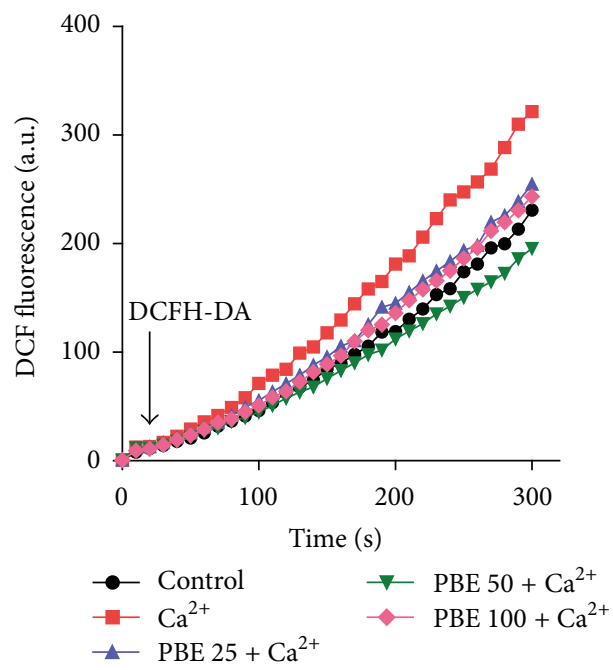

(e)

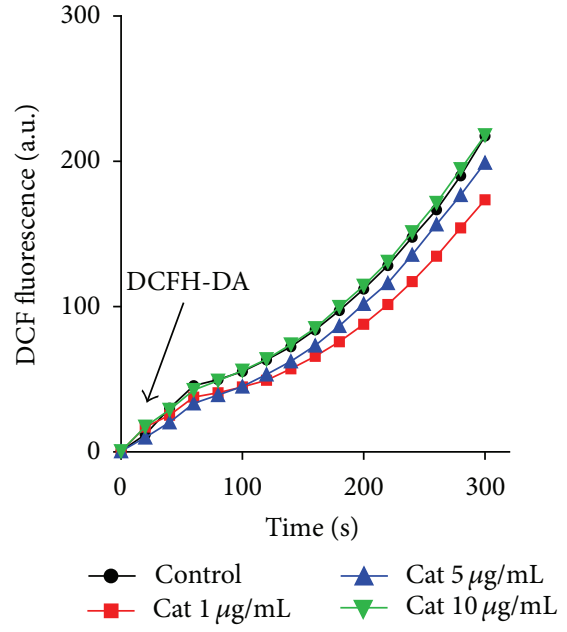

(b)

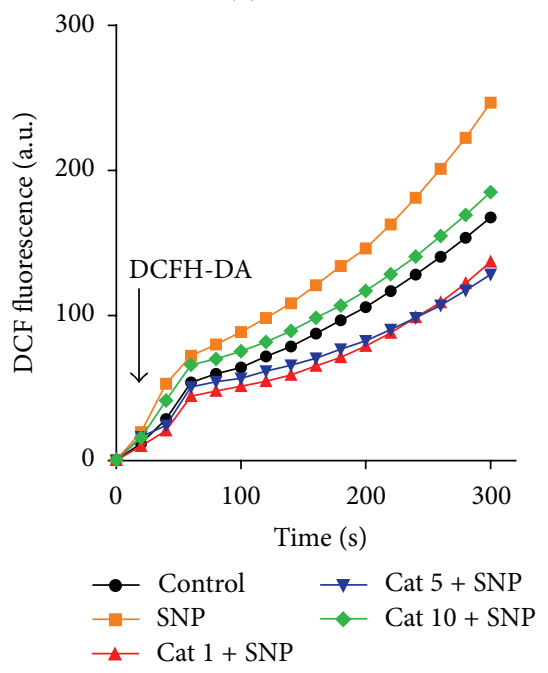

(d)

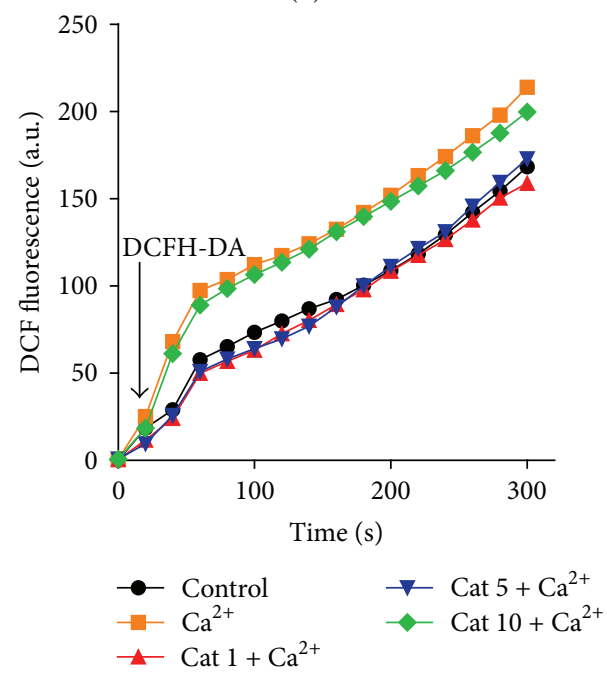

(f)

FIGURE 7: Effects of PBE and catechin on brain mitochondrial ROS production: SNP and $\mathrm{Ca}^{2+}$ interactions. Mitochondria were incubated in a medium containing $50 \mu \mathrm{M}$ EGTA, $10 \mathrm{mM}$ sucrose, $65 \mathrm{mM} \mathrm{KCl}, 5 \mathrm{mM}$ glutamate, $5 \mathrm{mM}$ succinate, and $10 \mathrm{mM} \mathrm{HEPES,} \mathrm{pH}=7.2$, and PBE $(25,50$, or $100 \mu \mathrm{g} / \mathrm{mL})$ or catechin $(1,5$, or $10 \mu \mathrm{g} / \mathrm{mL})$ in the presence or absence of $150 \mu \mathrm{M}$ SNP or $80 \mu \mathrm{M} \mathrm{CaCl}_{2}$ for $10 \mathrm{~s}$. The reaction was initiated by the addition of $2^{\prime}, 7^{\prime}$-dichlorofluorescein diacetate (DCFH-DA) and the fluorescence intensity emission arising from the oxidized fluorescent derivative (DCF) was measured over a $300 \mathrm{~s}$ period. Results are presented as mean \pm SEM of three independent experiments. Data analysis was done by two-way ANOVA, followed by Bonferroni posttests $(P<0.05$ was considered statistically significant). Indicators of statistical significance were not shown in the graphs above to avoid ambiguity. 


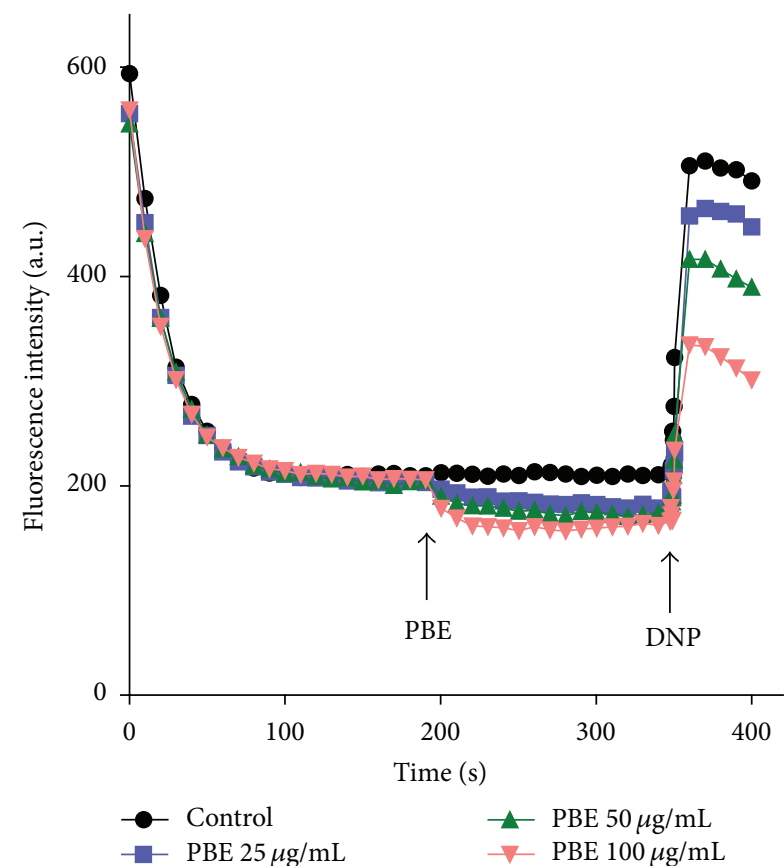

(a)

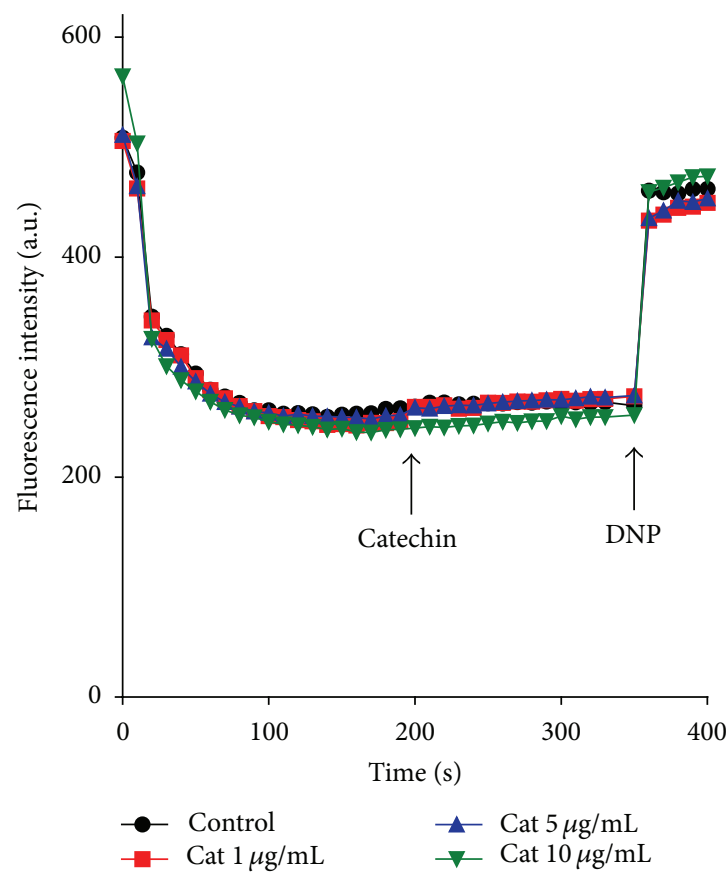

(c)

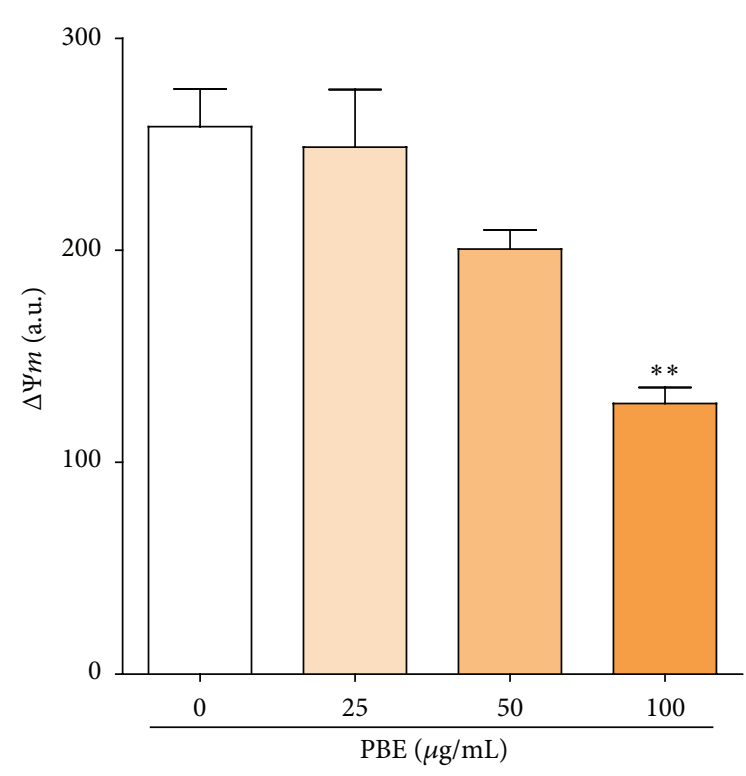

(b)

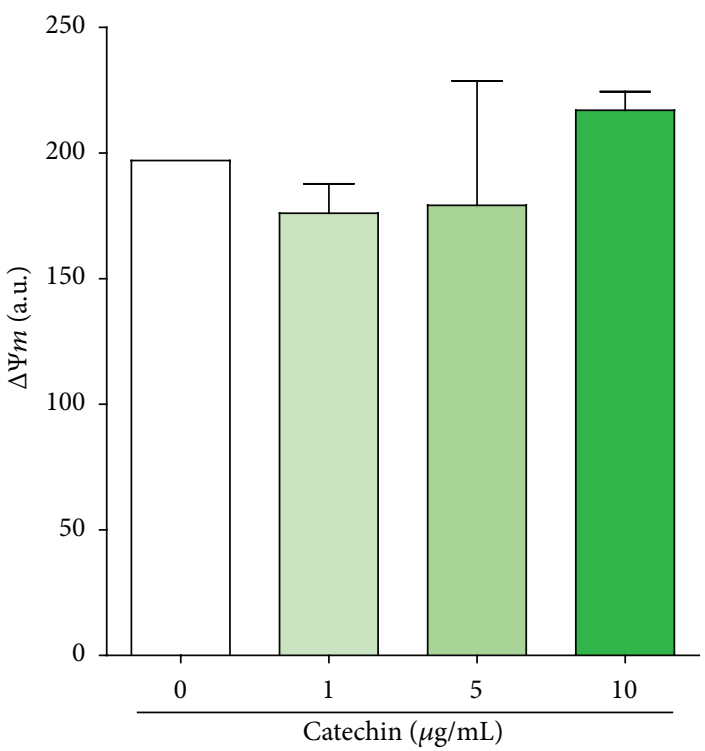

(d)

FIGURE 8: Effect of Parkia biglobosa leaf extract (PBE) (a) and catechin (c) on isolated rat brain mitochondrial potential and the respective potential difference $(\Delta \Psi m)(\mathrm{b})$ and $(\mathrm{d})$.

especially in the urban environments of some Asian and African countries [46]. $\mathrm{Pb}^{2+}$ can cause learning and memory impairment at the developmental stages and detrimental effects at blood levels as low as $5 \mu \mathrm{g} / \mathrm{dL}$ have been reported in children [47]. It is claimed that $\mathrm{Pb}$ exerts its toxicity via its inhibitory effect on the $\mathrm{N}$-methyl-D-aspartate receptors in the hippocampus. Chronic exposure to low dose of the metal was shown to cause reduction in $\mathrm{Ca}^{2+}$-dependent glutamate and $\gamma$-aminobutyric acid (GABA) release in the hippocampus and overall presynaptic neuron dysfunction in rats [48, 49]. The freely diffusible and stable ROS, $\mathrm{H}_{2} \mathrm{O}_{2}$, could induce oxidative stress by promoting calcium influx and interacting with iron or copper to generate toxic ROS, including the highly potent hydroxyl radical which can result in neuronal 
cell death $[50,51] . \mathrm{H}_{2} \mathrm{O}_{2}$ has been postulated to be involved in neurodegenerative disease and the neuronal injury and death induced by amyloid beta protein and glutamate [51]. Excessive calcium and lead could facilitate the generation of reactive oxygen species in biological systems. Oxidative stress-mediated cellular damage and loss of cellular viability may be involved in some of the pathologies associated with lead toxicity [52]. Elevated blood-lead concentration has been correlated with reduced level of antioxidant molecules like $\alpha$-tocopherol and ascorbic acid in human [53]. Since both lead and $\mathrm{H}_{2} \mathrm{O}_{2}$ display oxidative stress-dependent approach to their toxicity, it is only logical to assume that antioxidants could be a vital component of an effective treatment. The catechins are strong scavengers of reactive oxygen and nitric radicals as well as effective metal chelators owing to their catechol structures [54]. The observed improvement of the viability of $\mathrm{H}_{2} \mathrm{O}_{2}$ - and $\mathrm{PbCl}_{2}$-treated hippocampal cells by catechin in the present study could therefore be attributed, at least in part, to the antioxidant property of the polyphenol. We recently suggested that antioxidant activity and beneficial control of metal ion homeostasis in the cerebral system could be important neuroprotective strategies by some medicinal plants or other agents against neurodegenerative diseases like Alzheimer's and Parkinson's [55].

In the present study, whereas catechin prevented both the increased lipid peroxidation and reduced viability of hippocampal cells exposed to lead, PBE inhibited membrane peroxidation and increased thiol contents only. Elevation of membrane lipid peroxidation products and depletion of GSH levels in cells depict oxidative stress condition which could result in loss of cellular viability. The observation in the present study, however, that attenuation of oxidative stress condition in hippocampal cells by both PBE and catechin did not always translate to significant improvement in cellular viability however could be as a result of the relatively short incubation time with the extract or its major polyphenol.

Dysregulation of calcium signaling and the consequent generation of reactive oxygen and nitrogen species including nitric oxide (NO) have been implicated in mitochondrial dysfunction and of great significance in neurodegenerative disease [3]. In neuronal mitochondria, overproduction of NO make it readily available to react rapidly with the superoxide radical $\left(\mathrm{O}_{2}{ }^{--}\right)$forming the very toxic peroxynitrite (ONOO-) and the consequent oxidative stress-mediated damage. In this regard, a possible pharmacological strategy to neurodegenerative diseases was suggested to be the prevention of $\mathrm{Ca}^{2+}$ mediated nitrosative stress [3]. The nitric oxide (NO) donor, sodium nitroprusside (SNP), has been reported to exhibit deleterious effect on mitochondrial function and has been capable of inhibiting the activity of complex IV of the mitochondrial electron transport chain (MTC) with consequent apoptotic cell death [56]. In the present study, both PBE at all concentrations used and catechin were effective in blunting SNP and $\mathrm{Ca}^{2+}$-dependent ROS generation in the mitochondria. In line with a previous finding [57] we hypothesize a direct scavenging of nitric oxide (NO) and superoxide radicalv $\left(\mathrm{O}_{2}{ }^{--}\right)$by PBE through its phenolic constituents like catechin and other flavan-3-ols even though other mechanisms are not ruled out. We recently reported the protection against liver mitochondria damage by a plant extract through one or more of its antioxidant phytochemicals via antioxidant and Fe (II) chelating mechanisms [58].

Given the effect of both PBE and catechin on the $\triangle \Psi m$, the propensity of PBE for mild depolarization of the brain mitochondrial membrane potential could not be dependent on the catechin polyphenols but probably on one or more other phytoconstituents or the interactions among these. The neuroprotective effect of a plant extract was once attributed to the mild depolarization of $\Delta \Psi m$ [59]. The mitochondrial membrane potential $(\Delta \Psi m)$ contributes significantly to the extent of ROS production and with increased production occurring at high potentials [60]. The effect of PBE on $\Delta \Psi m$ might be responsible for its superior efficacy in attenuating mitochondrial ROS formation compared to catechin alone. "Mild uncoupling" of mitochondria is believed to be turned on in vivo to diminish the formation of ROS [61] even though the mechanisms involved in this regulation of $\Delta \Psi m$ are complex and not fully understood. Such decrease in the mitochondrial membrane potential $(\Delta \Psi m)$ primarily attenuates mitochondrial ROS production with consequential decrease in mitochondrial $\mathrm{Ca}^{2+}$ uptake [62], preventing mitochondrial calcium overload and the subsequent apoptosis [63] of the neurons.

To provide further insight into mechanisms of PBE neuroprotectivity, we investigated the effect on cerebral acetylcholinesterase and $\mathrm{Na}^{+}, \mathrm{K}^{+}$-ATPase activity which are both enzymes of neurological significance. Neither PBE nor catechin at the study concentrations possesses any inhibitory effect on the acetylcholinesterase enzyme but the result of $\mathrm{PBE}$ treatment revealed that the plant extract could boost the activity of $\mathrm{Na}^{+} / \mathrm{K}^{+}$-ATPase in the cerebral tissue. Since $\mathrm{Na}^{+}, \mathrm{K}^{+}$-ATPase is essential to brain normal function, modulation of this enzyme might contribute to the therapeutic efficacy and the neuroprotective effects of Parkia biglobosa. Some cases of psychiatric disorders are known to involve disruption in ion homeostasis and are often characterized by decreased $\mathrm{Na}^{+}, \mathrm{K}^{+}$-ATPase activity $[12,64]$. Decreased $\mathrm{Na}^{+}, \mathrm{K}^{+}$-ATPase activity in the hippocampus of animals submitted to chronic mild stress was also reported [65]. By implication, drugs or natural products capable of augmenting the activity of this enzyme in such instances may be of immense benefit in ensuring the maintenance of the critical electrochemical gradient necessary for neuronal functions and hence neuronal viability.

Notwithstanding the observed effect of PBE on mitochondrial redox status and hippocampal cells viability, especially considering that the extract is a complex mixture of phytochemicals, it is impossible to extrapolate the findings from this in vitro study to in vivo situation. In vivo studies are still necessary to define the concentrations that could exert biological effects. However, considering the beneficial effects of catechin and other polyphenol constituents of $\mathrm{PBE}$ and the literature points of evidence, indicating the absorption of these components in mammals, we can suggest that sufficient absorption could occur to reach biologically relevant concentrations in the bloodstream $[66,67]$. 


\section{Conclusion}

In summary, the results presented here suggest that $\mathrm{PBE}$ did exhibit neuroprotectivity by attenuating toxicant-induced ROS and oxidative stress in cerebral mitochondria and hippocampal tissue and boosting $\mathrm{Na}^{+}, \mathrm{K}^{+}$-ATPase activity. The neuroprotective effect of $P$. biglobosa might be partly related to the antioxidant phenolics as well as its mild mitochondrial depolarization propensity by yet to be identified phytoconstituent(s) and in yet to be clarified mechanism(s). However, the results presented here cannot be extrapolated to in vivo situations, which is a limitation of the present study. Consequently, in vivo studies are needed to make appropriate assumptions about the safety and effectiveness of this plant extract as neuroprotective agent in mammals.

\section{Conflict of Interests}

The authors declare that there is no conflict of interests regarding the publication of this paper.

\section{Acknowledgment}

One of the authors (Kayode Komolafe) is indebted to TWASCNPQ for a doctoral fellowship (FR no. 3240256075) and financial support of FAPERGS-PRONEX.

\section{References}

[1] B. Halliwell, "Role of free radicals in the neurodegenerative diseases: therapeutic implications for antioxidant treatment," Drugs and Aging, vol. 18, no. 9, pp. 685-716, 2001.

[2] J. Luo and R. Shi, "Acrolein induces oxidative stress in brain mitochondria," Neurochemistry International, vol. 46, no. 3, pp. 243-252, 2005.

[3] T. Nakamura and S. A. Lipton, "Preventing $\mathrm{Ca}^{2+}$-mediated nitrosative stress in neurodegenerative diseases: possible pharmacological strategies," Cell Calcium, vol. 47, no. 2, pp. 190-197, 2010.

[4] D. Blum, S. Torch, N. Lambeng et al., "Molecular pathways involved in the neurotoxicity of 6-OHDA, dopamine and MPTP: Contribution to the apoptotic theory in Parkinson's disease," Progress in Neurobiology, vol. 65, no. 2, pp. 135-172, 2001.

[5] S. Mandel, O. Weinreb, and M. B. H. Youdim, "Using cDNA microarray to assess Parkinson's disease models and the effects of neuroprotective drugs," Trends in Pharmacological Sciences, vol. 24, no. 4, pp. 184-191, 2003.

[6] M. Vila and S. Przedborski, "Targeting programmed cell death in neurodegenerative diseases," Nature Reviews Neuroscience, vol. 4, no. 5, pp. 365-375, 2003.

[7] S. A. Mandel, T. Amit, O. Weinreb, and M. B. H. Youdim, "Understanding the broad-spectrum neuroprotective action profile of green tea polyphenols in aging and neurodegenerative diseases," Journal of Alzheimer's Disease, vol. 25, no. 2, pp. 187208, 2011.

[8] A. Boveris and B. Chance, "The mitochondrial generation of hydrogen peroxide: general properties and effect of hyperbaric oxygen," Biochemical Journal, vol. 134, no. 3, pp. 707-716, 1973.
[9] H. H. Szeto, "Cell-permeable, mitochondrial-targeted, peptide antioxidants," The American Association of Pharmaceutical Scientists Journal, vol. 8, pp. E277-E283, 2006.

[10] M. F. Beal, "Mitochondrial dysfunction in neurodegenerative diseases," Biochimica et Biophysica Acta: Bioenergetics, vol. 1366, no. 1-2, pp. 211-223, 1998.

[11] O. Kann and R. Kovács, "Mitochondria and neuronal activity," American Journal of Physiology-Cell Physiology, vol. 292, no. 2, pp. 641-657, 2007.

[12] A. P. S. de Vasconcellos, A. I. Zugno, A. H. D. P. Dos Santos et al., " $\mathrm{Na}^{+}, \mathrm{K}^{+}$-ATPase activity is reduced in hippocampus of rats submitted to an experimental model of depression: effect of chronic lithium treatment and possible involvement in learning deficits," Neurobiology of Learning and Memory, vol. 84, no. 2, pp. 102-110, 2005.

[13] J. P. Kamdem, E. P. Waczuk, I. J. Kade et al., "Catuaba (Trichilia catigua) prevents against oxidative damage induced by in vitro ischemia-reperfusion in rat hippocampal slices," Neurochemical Research, vol. 37, no. 12, pp. 2826-2835, 2012.

[14] R. P. Pereira, R. Fachinetto, A. De Souza Prestes et al., "Antioxidant effects of different extracts from Melissa officinalis, Matricaria recutita and Cymbopogon citratus," Neurochemical Research, vol. 34, no. 5, pp. 973-983, 2009.

[15] J. H. Sudati, R. Fachinetto, R. P. Pereira et al., "In vitro antioxidant activity of valeriana officinalis against different neurotoxic agents," Neurochemical Research, vol. 34, no. 8, pp. 1372-1379, 2009.

[16] C. Wagner, A. P. Vargas, D. H. Roos et al., "Comparative study of quercetin and its two glycoside derivatives quercitrin and rutin against methylmercury ( $\mathrm{MeHg}$ )-induced ROS production in rat brain slices," Archives of Toxicology, vol. 84, no. 2, pp. 89-97, 2010.

[17] C. E. Udobi, J. A. Onaolapo, and A. Agunu, "Antibacterial potentials of the methanolic extract and aqueous fraction of the stem bark of the African locust bean (Parkia Biglobosa)," European Journal of Scientific Research, vol. 43, no. 4, pp. 590597,2010

[18] A. A. Aiyeloja and O. A. Bello, "Ethnobotanical potentials of common herbs in Nigeria: a case study of Enugu state," Educational Research and Review, vol. 1, pp. 16-22, 2006.

[19] H. Millogo-Kone, I. P. Guissou, O. Nacoulma, and A. S. Traore, "Comparative study of leaf and stem bark extracts of Parkia Biglobosa against enterobacteria," African Journal of Traditional, Complementary Alternative Medicine, vol. 5, pp. 238-243, 2008.

[20] T. M. Olaleye, K. Komolafe, and A. A. Akindahunsi, "Effect of methanolic leaf extract of Parkia biglobosa on some biochemical indices and hemodynamic parameters in rats," Journal of Chemical and Pharmaceutical Research, vol. 5, no. 1, pp. 213-220, 2013.

[21] K. Komolafe, M. T. Olaleye, A. A. Boligon, M. L. Athayde, A. A. Akindahunsi, and J. B. T. Rocha, "Antioxidant activity and modulation of mitochondrial redox status by Parkia biglobosa leaf,' Asian Pacific Journal of Tropical Medicine. In press.

[22] K. Komolafe, M. T. Olaleye, T. I. Fasan, O. O. Elekofehinti, J. A. Saliu, and A. A. Akindahunsi, "Lowering effect of Parkia biglobosa leaf saponins in Triton-X 1339-induced hyperlipidemic rats," Research Journal of Pharmaceutical, Biological and Chemical Sciences, vol. 4, no. 1, pp. 576-585, 2013.

[23] A. A. Akindahunsi and M. T. Olaleye, "Toxicological investigation of aqueous-methanolic extract of the calyces of Hibiscus sabdariffa L," Journal of Ethnopharmacology, vol. 89, no. 1, pp. 161-164, 2003. 
[24] A. M. Salah, J. Gathumbi, and W. Vierling, "Inhibition of intestinal motility by methanol extracts of Hibiscus sabdariffa L. (Malvaceae) in rats," Phytotherapy Research, vol. 16, no. 3, pp. 283-285, 2002.

[25] S. M. Sabir, S. D. Ahmad, A. Hamid et al., "Antioxidant and hepatoprotective activity of ethanolic extract of leaves of Solidago microglossa containing polyphenolic compounds," Food Chemistry, vol. 131, no. 3, pp. 741-747, 2012.

[26] ICH, "Text on validation of analytical procedures: methodology: Q2 (R1)," 2005, http://www.ich.org/.

[27] T. Mosmann, "Rapid colorimetric assay for cellular growth and survival: application to proliferation and cytotoxicity assays," Journal of Immunological Methods, vol. 65, no. 1-2, pp. 55-63, 1983.

[28] I. R. Siqueira, H. Cimarosti, C. Fochesatto et al., "Neuroprotective effects of Ptychopetalum olacoides Bentham (Olacaceae) on oxygen and glucose deprivation induced damage in rat hippocampal slices,' Life Sciences, vol. 75, no. 15, pp. 1897-1906, 2004.

[29] P. Pérez-Severiano, M. Rodríguez-Pérez, J. Pedraza-Chaverrí et al., "S-allylcysteine, a garlic-derived antioxidant, ameliorates quinolinic acid-induced neurotoxicity and oxidative damage in rats," Neurochemistry International, vol. 45, pp. 1175-1183, 2004.

[30] M. M. Bradford, "A rapid and sensitive method for the quantitation of microgram quantities of protein utilizing the principle of protein dye binding," Analytical Biochemistry, vol. 72, no. 1-2, pp. 248-254, 1976.

[31] G. L. Ellman, “Tissue sulfhydryl groups," Archives of Biochemistry and Biophysics, vol. 82, no. 1, pp. 70-77, 1959.

[32] A. T. S. Wyse, E. L. Streck, S. V. T. Barros, A. M. Brusque, A. I. Zugno, and M. Wajner, "Methylmalonate administration decreases $\mathrm{Na}^{+}, \mathrm{K}^{+}$-ATPase activity in cerebral cortex of rats," NeuroReport, vol. 11, no. 10, pp. 2331-2334, 2000.

[33] C. H. Fiske and Y. Subbarow, "The colorimetric determination of phosphorous," The Journal of Biological Chemistry, vol. 66, pp. 375-400, 1925.

[34] G. L. Ellman, K. D. Courtney, V. Andres Jr., and R. M. Featherstone, "A new and rapid colorimetric determination of acetylcholinesterase activity," Biochemical Pharmacology, vol. 7, no. 2, pp. 88-95, 1961.

[35] N. Brustovetsky and J. M. Dubinsky, "Dual responses of CNS mitochondria to elevated calcium," The Journal of Neuroscience, vol. 20, no. 1, pp. 103-113, 2000.

[36] S. L. Hempel, G. R. O. Buettner, Y. Q. O’Malley, D. A. Wessels, and D. M. Flaherty, "Dihydrofluorescein diacetate is superior for detecting intracellular oxidants: comparison with $2^{\prime}, 7^{\prime}$ dichlorodihydrofluorescein diacetate, 5(and 6)-carboxy- $2^{\prime}, 7^{\prime}$ dichlorodihydrofluorescein diacetate, and dihydrorhodamine 123," Free Radical Biology \& Medicine, vol. 27, no. 1-2, pp. 146159, 1999.

[37] Z. Komary, L. Tretter, and V. Adam-Vizi, "Membrane potentialrelated effect of calcium on reactive oxygen species generation in isolated brain mitochondria," Biochimica et Biophysica ActaBioenergetics, vol. 1797, no. 6-7, pp. 922-928, 2010.

[38] S. Mandel and M. B. H. Youdim, "Catechin polyphenols: neurodegeneration and neuroprotection in neurodegenerative diseases," Free Radical Biology and Medicine, vol. 37, no. 3, pp. 304-317, 2004.

[39] L. Chen, X. Yang, H. Jiao, and B. Zhao, "Tea catechins protect against lead-induced ROS formation, mitochondrial dysfunction, and calcium dysregulation in PC12 cells," Chemical Research in Toxicology, vol. 16, no. 9, pp. 1155-1161, 2003.
[40] K. C. Kim, J. S. Kim, K. Ah Kang, J. M. Kim, and J. Won Hyun, "Cytoprotective effects of catechin 7-O- $\beta$-D glucopyranoside against mitochondrial dysfunction damaged by streptozotocin in RINm5F cells," Cell Biochemistry and Function, vol. 28, no. 8, pp. 651-660, 2010.

[41] B. S. McEwen, "Sex, stress and the hippocampus: allostasis, allostatic load and the aging process," Neurobiology of Aging, vol. 23, no. 5, pp. 921-939, 2002.

[42] S. Bastianetto and R. Quirion, "Natural extracts as possible protective agents of brain aging," Neurobiology of Aging, vol. 23, no. 5, pp. 891-897, 2002.

[43] B. Moosmann and C. Behl, "The antioxidant neuroprotective effects of estrogens and phenolic compounds are independent from their estrogenic properties," Proceedings of the National Academy of Sciences of the United States of America, vol. 96, no. 16, pp. 8867-8872, 1999.

[44] B. Halliwell and O. I. Aruoma, "DNA damage by oxygenderived species. Its mechanism and measurement in mammalian systems," FEBS Letters, vol. 281, no. 1-2, pp. 9-19, 1991.

[45] H. Lou, X. Jing, D. Ren, X. Wei, and X. Zhang, "Eriodictyol protects against $\mathrm{H}_{2} \mathrm{O}_{2}$-induced neuron-like PC12 cell death through activation of Nrf2/ARE signaling pathway," Neurochemistry International, vol. 61, no. 2, pp. 251-257, 2012.

[46] A. P. Neal and T. R. Guilarte, "Mechanisms of lead and manganese neurotoxicity," Toxicology Research, vol. 2, no. 2, pp. 99-114, 2013.

[47] M. M. Téllez-Rojo, D. C. Bellinger, C. Arroyo-Quiroz et al., "Longitudinal associations between blood lead concentrations lower than $10 \mu \mathrm{g} / \mathrm{dL}$ and neurobehavioral development in environmentally exposed children in Mexico City," Pediatrics, vol. 118, no. 2, pp. e323-e330, 2006.

[48] S. M. Lasley and M. E. Gilbert, "Rat hippocampal glutamate and GABA release exhibit biphasic effects as a function of chronic lead exposure level," Toxicological Sciences, vol. 66, no. 1, pp. 139-147, 2002.

[49] C. Xiao, Y. Gu, C. Y. Zhou, L. Wang, M. M. Zhang, and D. $\mathrm{Y}$. Ruan, " $\mathrm{Pb}^{2+}$ impairs GABAergic synaptic transmission in rat hippocampal slices: a possible involvement of presynaptic calcium channels," Brain Research, vol. 1088, no. 1, pp. 93-100, 2006.

[50] P. L. Lutz and S. L. Milton, "Negotiating brain anoxia survival in the turtle," Journal of Experimental Biology, vol. 207, no. 18, pp. 3141-3147, 2004.

[51] D. R. Palumbo, F. Occhiuto, F. Spadaro, and C. Circosta, "Rhodiola rosea extract protects human cortical neurons against glutamate and hydrogen peroxide-induced cell death through reduction in the accumulation of intracellular calcium," Phytotherapy Research, vol. 26, no. 6, pp. 878-883, 2012.

[52] L. Chen, X. Yang, H. Jiao, and B. Zhao, “Tea catechins protect against lead-induced cytotoxicity, lipid peroxidation, and membrane fluidity in HepG2 cells," Toxicological Sciences, vol. 69, no. 1, pp. 149-156, 2002.

[53] W. L. West, E. M. Knight, C. H. Edwards et al., "Maternal low level lead and pregnancy outcomes," Journal of Nutrition, vol. 124, no. 6, pp. 981S-986S, 1994.

[54] C. A. Rice-Evans, N. J. Miller, and G. Paganga, "Antioxidant properties of phenolic compounds," Trends in Plant Science, vol. 2, no. 4, pp. 152-159, 1997.

[55] J. P. Kamdem, A. Adeniran, A. A. Boligon et al., "Antioxidant activity, genotoxicity and cytotoxicity evaluation of lemon balm (Melissa officinalis L.) ethanolic extract: its potential role in 
neuroprotection," Industrial Crops and Products, vol. 51, pp. 2634, 2013.

[56] E. Maneiro, M. J. López-Armada, M. C. de Andres et al., "Effect of nitric oxide on mitochondrial respiratory activity of human articular chondrocytes," Annals of the Rheumatic Diseases, vol. 64, no. 3, pp. 388-395, 2005.

[57] T. Nakagawa and T. Yokozawa, "Direct scavenging of nitric oxide and superoxide by green tea," Food and Chemical Toxicology, vol. 40, no. 12, pp. 1745-1750, 2002.

[58] C. V. Klimaczewski, R. A. Saraiva, D. H. Ross et al., "Antioxidant activity of Peumus boldus extract and alkaloid boldine against damage induced by $\mathrm{Fe}(\mathrm{II})$-citrate in rat liver mitochondria in vitro," Industrial Crops and Products, vol. 54, pp. 240-247, 2014.

[59] J. Wu, Y. Cui, Y. Yang et al., "Mild mitochondrial depolarization is involved in a neuroprotective mechanism of Citrus sunki peel extract," Phytotherapy Research, vol. 27, no. 4, pp. 564-571, 2013.

[60] M. P. Murphy, "How mitochondria produce reactive oxygen species: a review," Biochemical Journal, vol. 417, no. 1, pp. 1-13, 2009.

[61] V. P. Skulachev, "Uncoupling: new approaches to an old problem of bioenergetics," Biochimica et Biophysica Acta, vol. 1363, no. 2, pp. 100-124, 1998.

[62] F. Sedlic, A. Sepac, D. Pravdic et al., "Mitochondrial depolarization underlies delay in permeability transition by preconditioning with isoflurane: Roles of ROS and $\mathrm{Ca}^{2+}$," The American Journal of Physiology-Cell Physiology, vol. 299, no. 2, pp. C506C515, 2010.

[63] E. M. Garcia-Martinez, S. Sanz-Blasco, A. Karachitos et al., "Mitochondria and calcium flux as targets of neuroprotection caused by minocycline in cerebellar granule cells," Biochemical Pharmacology, vol. 79, no. 2, pp. 239-250, 2010.

[64] L. Mynett-Johnson, V. Murphy, J. McCormack et al., "Evidence for an allelic association between bipolar disorder and a $\mathrm{Na}^{+}$, $\mathrm{K}^{+}$adenosine triphosphatase alpha subunit gene (ATP1A3)," Biological Psychiatry, vol. 44, no. 1, pp. 47-51, 1998.

[65] G. D. Gamaro, L. P. Manoli, I. L. S. Torres, R. Silveira, and C. Dalmaz, "Effects of chronic variate stress on feeding behavior and on monoamine levels in different rat brain structures," Neurochemistry International, vol. 42, no. 2, pp. 107-114, 2003.

[66] J. L. Donovan, J. R. Bell, S. Kasim-Karakas et al., "Catechin is present as metabolites in human plasma after consumption of red wine," Journal of Nutrition, vol. 129, no. 9, pp. 1662-1668, 1999.

[67] C. Manach, G. Williamson, C. Morand, A. Scalbert, and C. Rémésy, "Bioavailability and bioefficacy of polyphenols in humans. I. Review of 97 bioavailability studies," The American Journal of Clinical Nutrition, vol. 81, no. S1, pp. 230S-242S, 2005. 

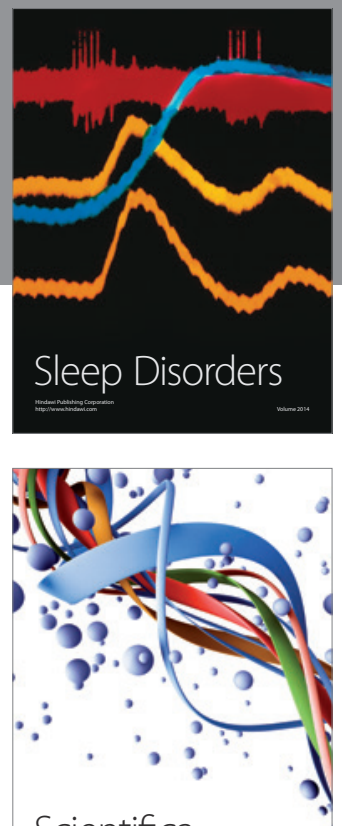

Scientifica
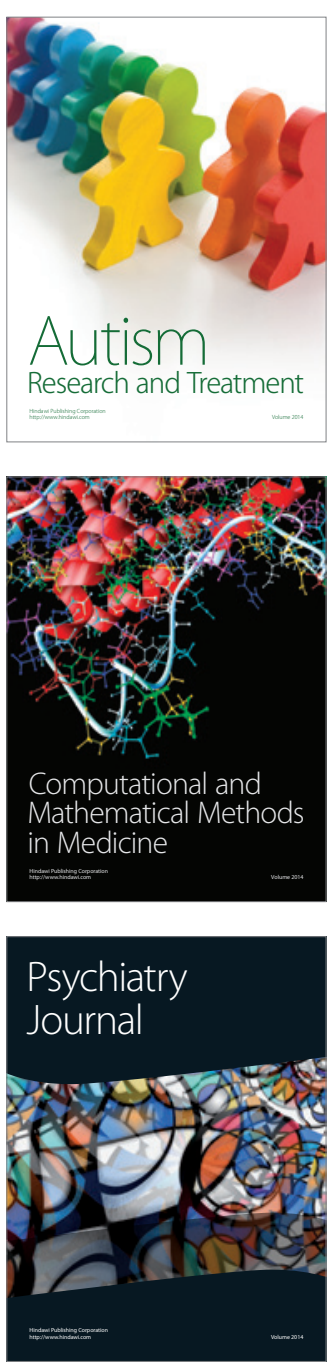
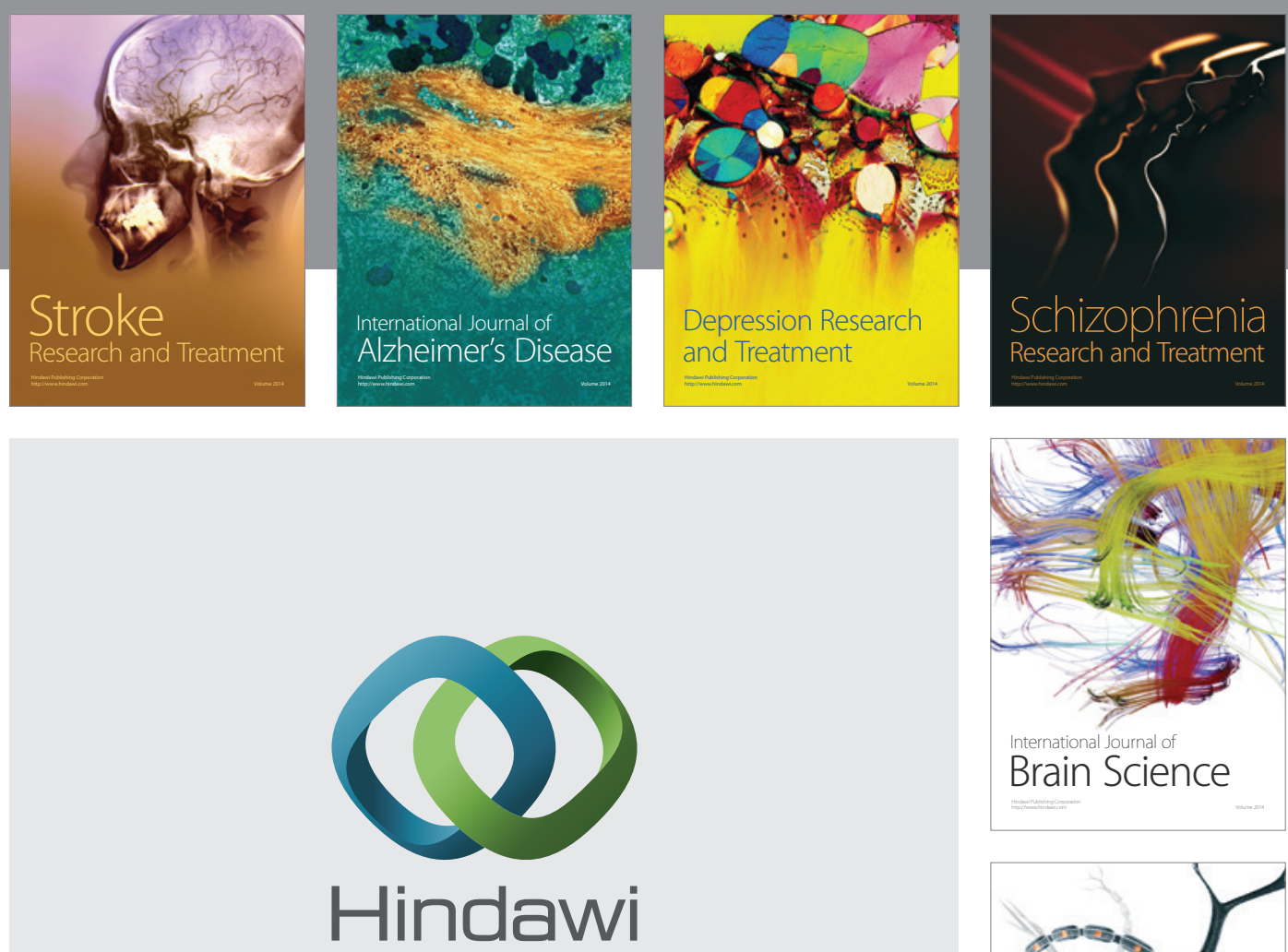

Submit your manuscripts at

http://www.hindawi.com
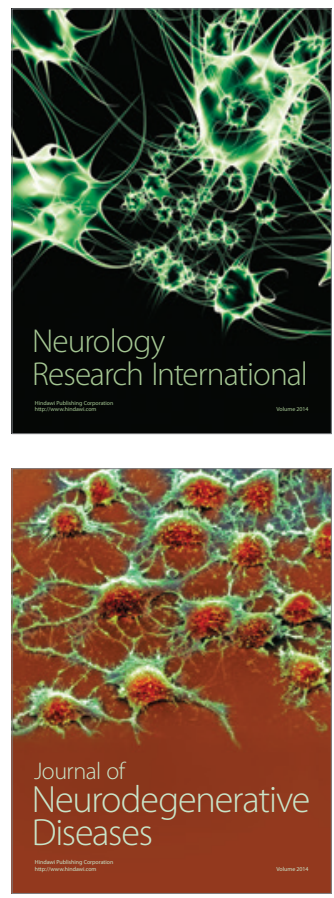

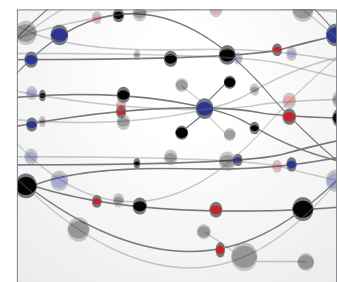

The Scientific World Journal
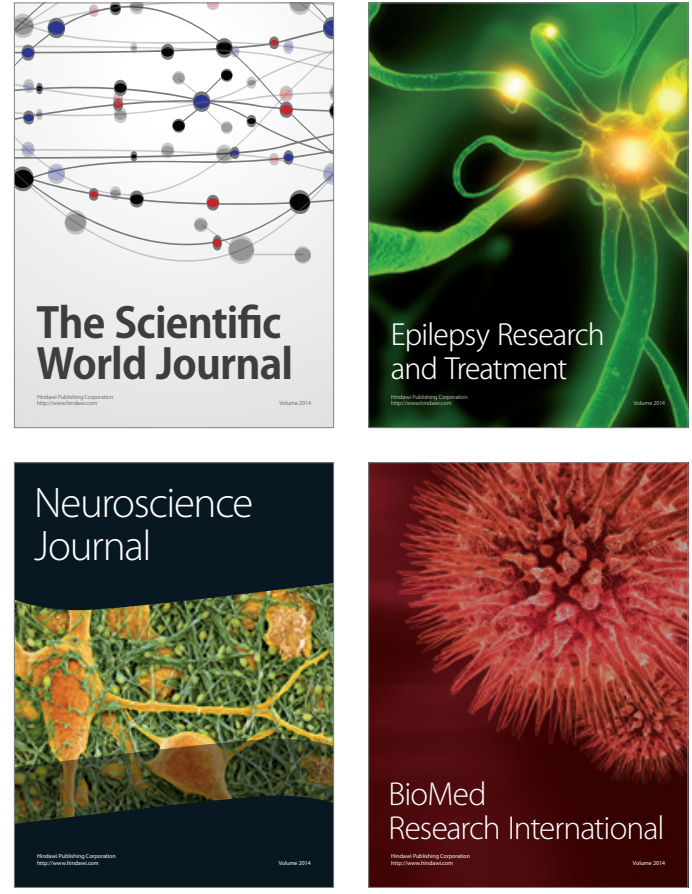

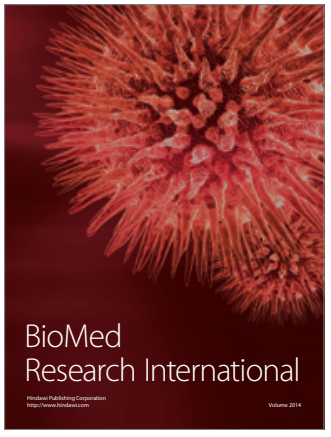

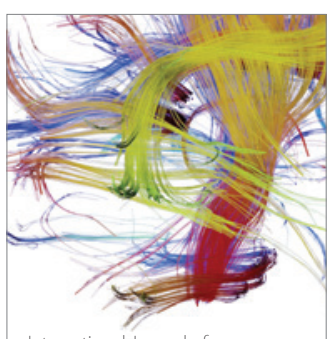

Brain Science

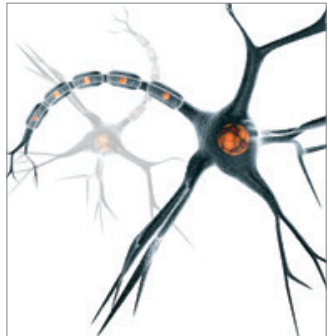

Neural Plasticity
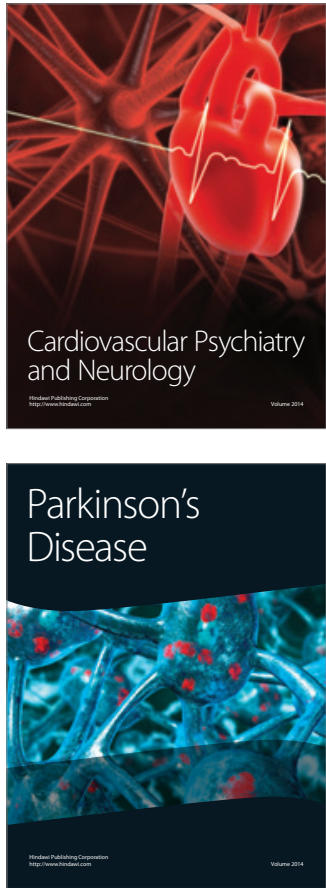